\title{
LEVEL II SCOUR ANALYSIS FOR BRIDGE 13 (CHESTH00060013) on TOWN HIGHWAY 6, crossing the WILLIAMS RIVER, CHESTER, VERMONT
}

Open-File Report 98-403

Prepared in cooperation with

VERMONT AGENCY OF TRANSPORTATION

and

FEDERAL HIGHWAY ADMINISTRATION

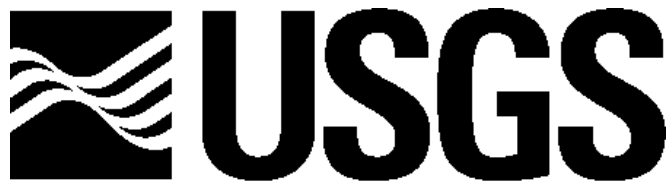

science for a changing world

U.S. Department of the Interior

U.S. Geological Survey 


\section{LEVEL II SCOUR ANALYSIS FOR BRIDGE 13 (CHESTH00060013) on TOWN HIGHWAY 6, crossing the WILLIAMS RIVER, CHESTER, VERMONT}

By MICHAEL A. IVANOFF AND LAURA MEDALIE

U.S. Geological Survey Open-File Report 98-403

Prepared in cooperation with

VERMONT AGENCY OF TRANSPORTATION

and

FEDERAL HIGHWAY ADMINISTRATION

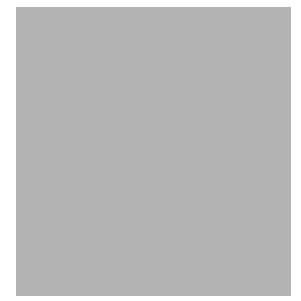




\title{
U.S. DEPARTMENT OF THE INTERIOR BRUCE BABBITT, Secretary
}

\author{
U.S. GEOLOGICAL SURVEY
}

Thomas J. Casadevall, Acting Director

For additional information write to:

District Chief

U.S. Geological Survey 361 Commerce Way

Pembroke, NH 03275-3718
Copies of this report may be purchased from:

U.S. Geological Survey

Branch of Information Services

Open-File Reports Unit

Box 25286

Denver, CO 80225-0286 


\section{CONTENTS}

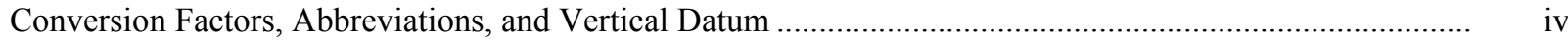

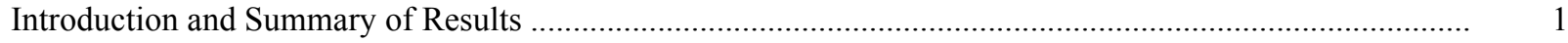

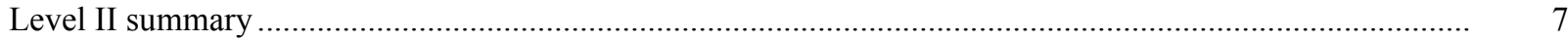

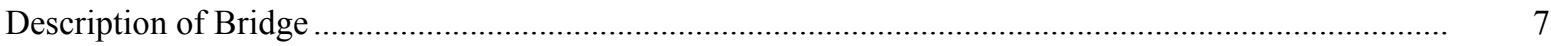

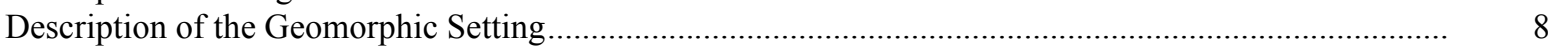

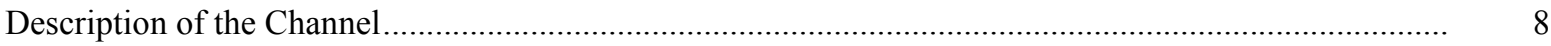

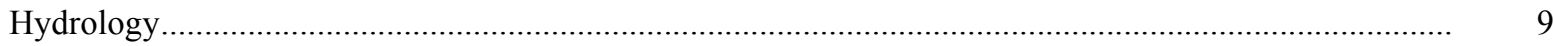

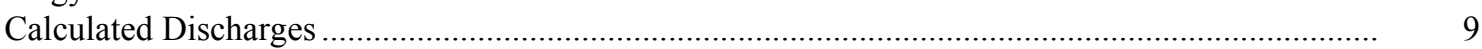

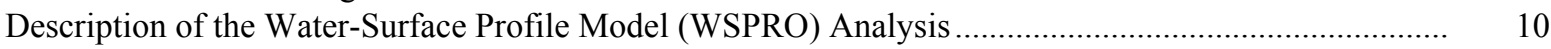

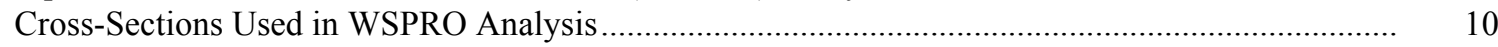

Data and Assumptions Used in WSPRO Model ........................................................................ 11

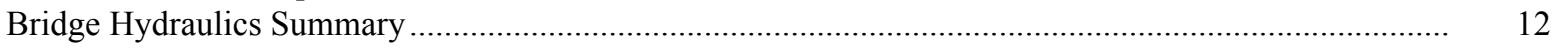

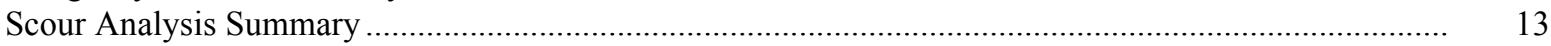

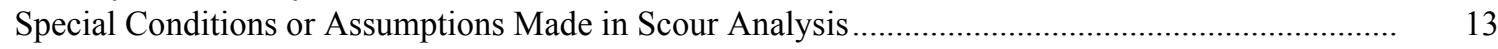

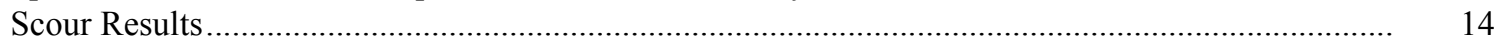

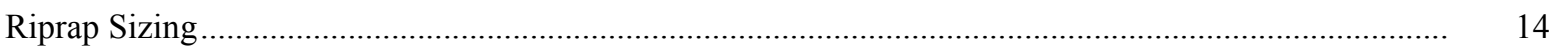

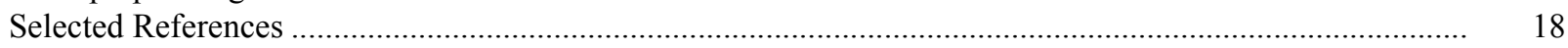

Appendices:

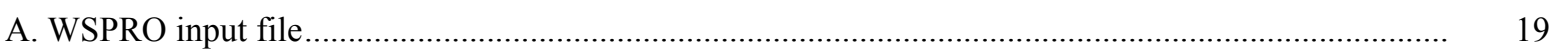

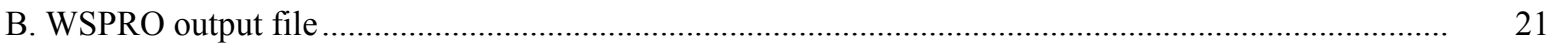

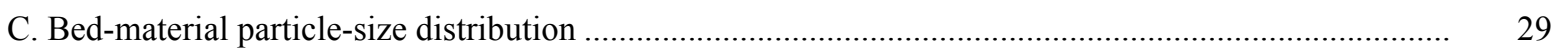

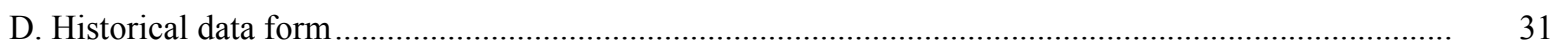

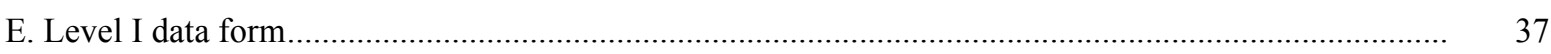

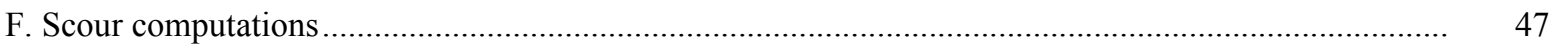

\section{FIGURES}

1. Map showing location of study area on USGS 1:25,000 scale map

2. Map showing location of study area on Vermont Agency of Transportation town highway map .....

3. Structure CHESTH00060013 viewed from upstream (August 19, 1996)....

4

5

4. Downstream channel viewed from structure CHESTH00060013 (August 19, 1996)............................. 5

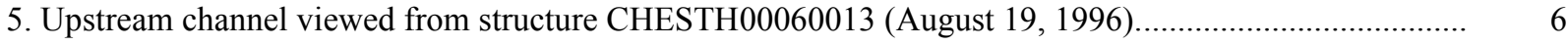

6. Structure CHESTH00060013 viewed from downstream (August 19, 1996).

7. Water-surface profiles for the 100- and 500-year discharges at structure

CHESTH00060013 on Town Highway 6, crossing the Williams River,

Chester, Vermont.

8. Scour elevations for the 100- and 500-year discharges at structure

CHESTH00060013 on Town Highway 6, crossing the Williams River,

Chester, Vermont.

\section{TABLES}

1. Remaining footing/pile depth at abutments for the 100-year discharge at structure

CHESTH00060013 on Town Highway 6, crossing the Williams River,

Chester, Vermont

2. Remaining footing/pile depth at abutments for the 500-year discharge at structure

CHESTH00060013 on Town Highway 6, crossing the Williams River,

Chester, Vermont 


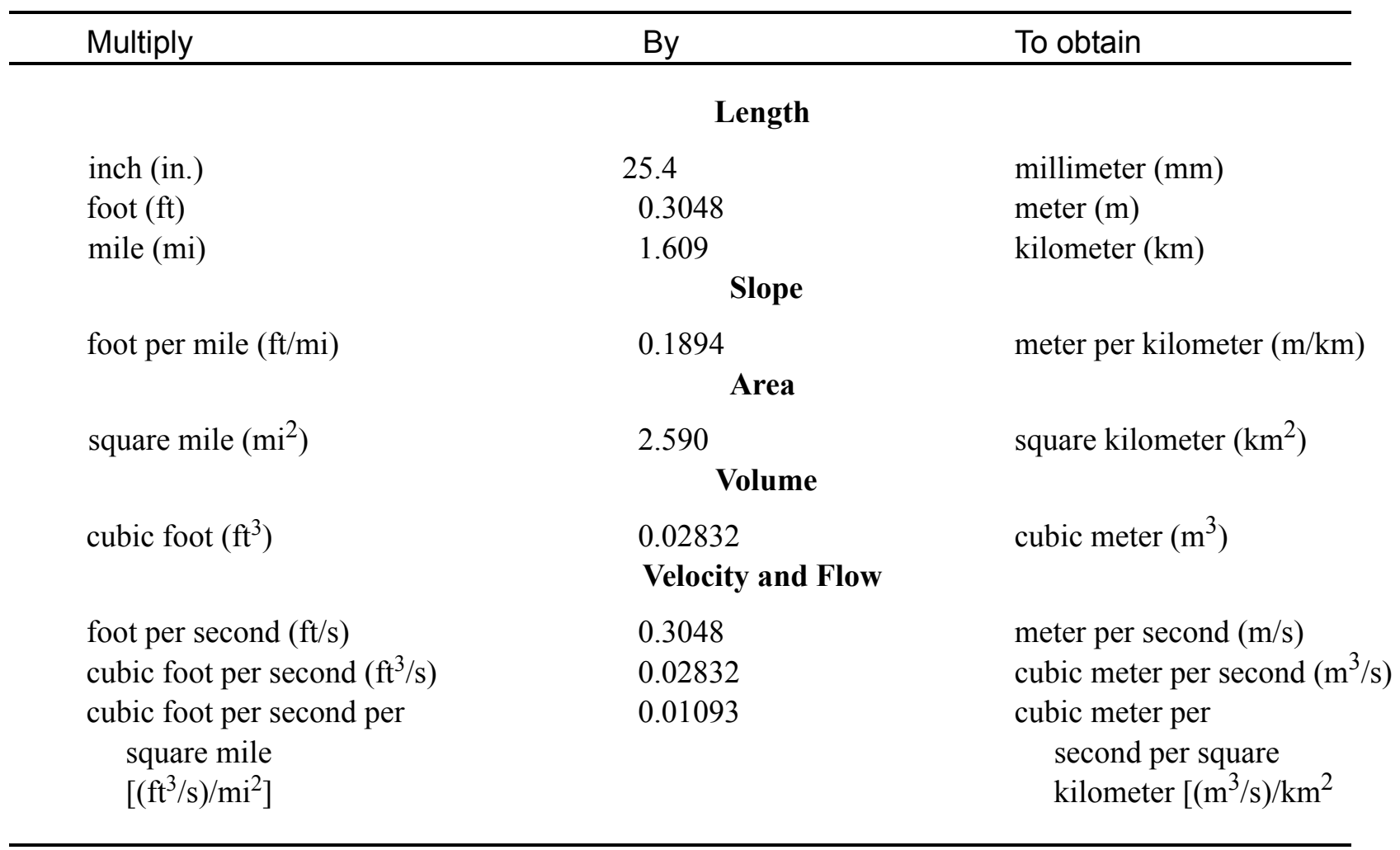

\section{OTHER ABBREVIATIONS}

$\begin{array}{lrlr}\mathrm{BF} & \text { bank full } & \text { LWW } & \text { left wingwall } \\ \mathrm{cfs} & \text { cubic feet per second } & \text { Max } & \text { maximum } \\ \mathrm{D}_{50} & \text { median diameter of bed material } & \text { MC } & \text { main channel } \\ \mathrm{DS} & \text { downstream } & \text { RAB } & \text { right abutment } \\ \mathrm{elev} & \text { elevation } & \text { RABUT } & \text { face of right abutment } \\ \mathrm{f} / \mathrm{p} & \text { flood plain } & \text { RB } & \text { right bank } \\ \mathrm{ft} & \text { square feet } & \text { ROB } & \text { right overbank } \\ \mathrm{ft} / \mathrm{ft} & \text { feet per foot } & \text { RWW } & \text { right wingwall } \\ \mathrm{FEMA} & \text { Federal Emergency Management Agency } & \text { TH } & \text { town highway } \\ \mathrm{FHWA} & \text { Federal Highway Administration } & \text { UB } & \text { under bridge } \\ \mathrm{JCT} & \text { junction } & \text { US } & \text { upstream } \\ \text { LAB } & \text { left abutment } & \text { USGS } & \text { United States Geological Survey } \\ \text { LABUT } & \text { face of left abutment } & \text { VTAOT } & \text { Vermont Agency of Transportation } \\ \text { LB } & \text { left bank } & \text { WSPRO } & \text { water-surface profile model } \\ \text { LOB } & \text { left overbank } & \text { yr } & \text { year }\end{array}$

In this report, the words "right" and "left" refer to directions that would be reported by an observer facing downstream. Sea level: In this report, "sea level" refers to the National Geodetic Vertical Datum of 1929-- a geodetic datum derived from a general adjustment of the first-order level nets of the United States and Canada, formerly called Sea Level Datum of 1929.

In the appendices, the above abbreviations may be combined. For example, USLB would represent upstream left bank. 


\title{
LEVEL II SCOUR ANALYSIS FOR BRIDGE 13 (CHESTH00060013) ON TOWN HIGHWAY 6, CROSSING THE WILLIAMS RIVER, CHESTER, VERMONT
}

\author{
By Michael A. Ivanoff and Laura Medalie
}

\section{INTRODUCTION AND SUMMARY OF RESULTS}

This report provides the results of a detailed Level II analysis of scour potential at structure CHESTH00060013 on Town Highway 6 crossing the Williams River, Chester, Vermont (figures 1-8). A Level II study is a basic engineering analysis of the site, including a quantitative analysis of stream stability and scour (FHWA, 1993). Results of a Level I scour investigation also are included in appendix E of this report. A Level I investigation provides a qualitative geomorphic characterization of the study site. Information on the bridge, gleaned from Vermont Agency of Transportation (VTAOT) files, was compiled prior to conducting Level I and Level II analyses and is found in appendix D.

The site is in the New England Upland section of the New England physiographic province in south eastern Vermont. The $80.6-\mathrm{mi}^{2}$ drainage area is in a predominantly rural and forested basin. In the vicinity of the study site, the surface cover is pasture on the right bank downstream of the bridge while the immediate banks have dense woody vegetation. There are row crops along the left bank. The right bank upstream of the bridge is forested.

In the study area, the Williams River has a sinuous channel with a slope of approximately $0.008 \mathrm{ft} / \mathrm{ft}$, an average channel top width of $129 \mathrm{ft}$ and an average bank height of $8 \mathrm{ft}$. The channel bed material ranges from gravel to boulder with a median grain size $\left(D_{50}\right)$ of 97.4 $\mathrm{mm}(0.320 \mathrm{ft})$. The geomorphic assessment at the time of the Level I and Level II site visit on August 19, 1996, indicated that the reach was stable.

The Town Highway 6 crossing of the Williams River is a 82-ft-long, one-lane bridge consisting of one 78-foot steel-beam span (Vermont Agency of Transportation, written communication, April 5, 1995). The opening length of the structure parallel to the bridge face is $75.7 \mathrm{ft}$. The bridge is supported by vertical, concrete abutments. The channel is skewed approximately zero degrees to the opening while the opening-skew-to-roadway is also zero degrees. 
A scour hole $2.0 \mathrm{ft}$ deeper than the mean thalweg depth was observed along the right abutment during the Level I assessment. The scour protection counter measures at the site included type- 2 stone fill (less than 36 inches diameter) at the upstream and downstream ends of the right abutment, along the upstream left bank, and along the downstream left and right banks and type-4 stone fill (less than 60 inches diameter) along the upstream right bank. Additional details describing conditions at the site are included in the Level II Summary and appendices D and E.

Scour depths and recommended rock rip-rap sizes were computed using the general guidelines described in Hydraulic Engineering Circular 18 (Richardson and Davis, 1995) for the 100- and 500-year discharges. In addition, the incipient roadway-overtopping discharge was determined and analyzed as another potential worst-case scour scenario. Total scour at a highway crossing is comprised of three components: 1) long-term streambed degradation; 2) contraction scour (due to accelerated flow caused by a reduction in flow area at a bridge) and; 3 ) local scour (caused by accelerated flow around piers and abutments). Total scour is the sum of the three components. Equations are available to compute depths for contraction and local scour and a summary of the results of these computations follows.

Contraction scour for all modelled flows ranged from 0.0 to $0.9 \mathrm{ft}$. The worst-case contraction scour occurred at the incipient roadway-overtopping discharge. Abutment scour ranged from 4.9 to $26.8 \mathrm{ft}$. The worst-case abutment scour occurred at the 500 -year discharge. Additional information on scour depths and depths to armoring are included in the section titled "Scour Results". Scoured-streambed elevations, based on the calculated scour depths, are presented in tables 1 and 2. A cross-section of the scour computed at the bridge is presented in figure 8 . Scour depths were calculated assuming an infinite depth of erosive material and a homogeneous particle-size distribution.

It is generally accepted that the Froehlich equation (abutment scour) gives "excessively conservative estimates of scour depths" (Richardson and Davis, 1995, p. 46). Usually, computed scour depths are evaluated in combination with other information including (but not limited to) historical performance during flood events, the geomorphic stability assessment, existing scour protection measures, and the results of the hydraulic analyses. Therefore, scour depths adopted by VTAOT may differ from the computed values documented herein. 


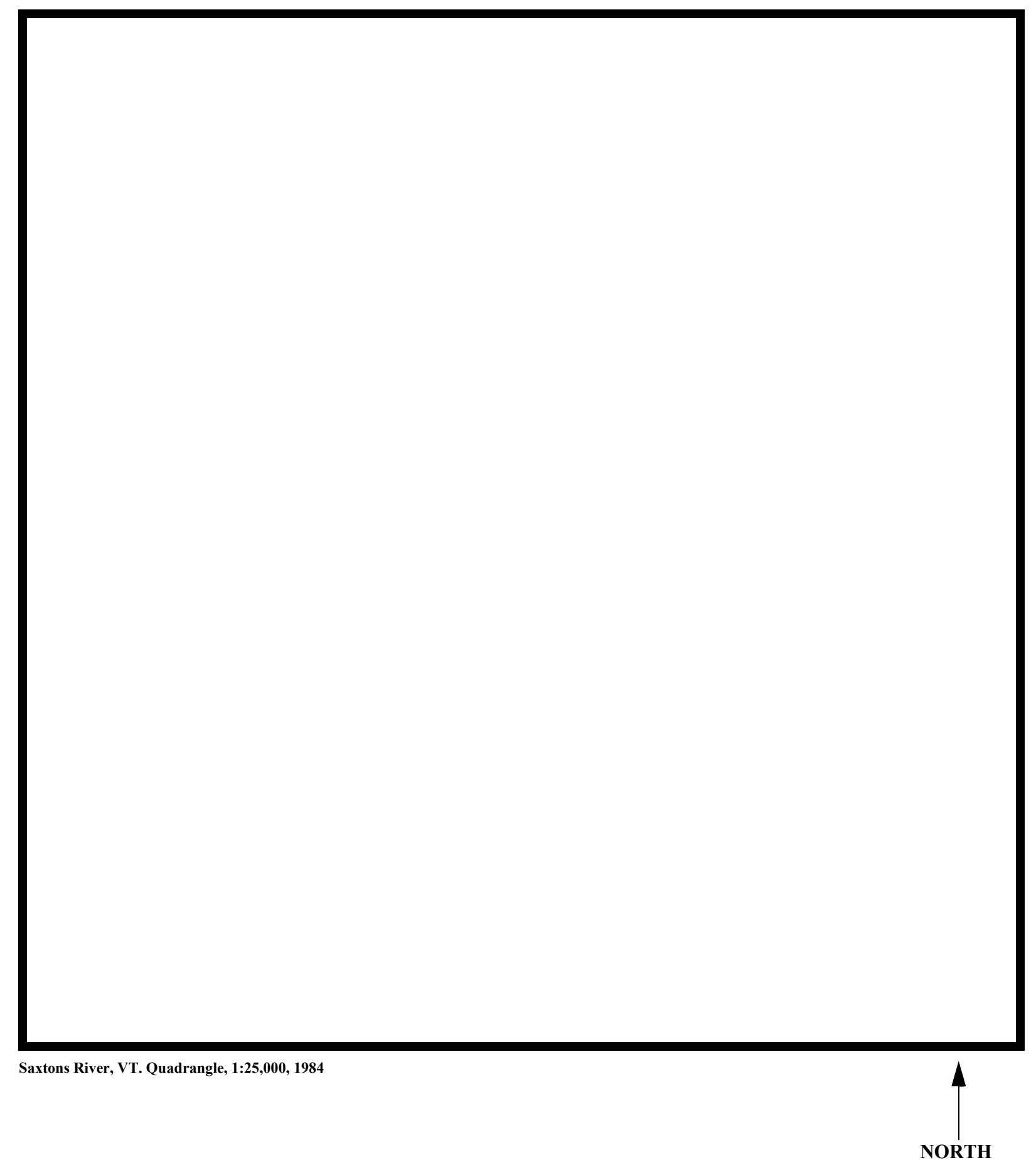

Figure 1. Location of study area on USGS 1:25,000 scale map. 
Figure 2. Location of study area on Vermont Agency of Transportation town highway map. 

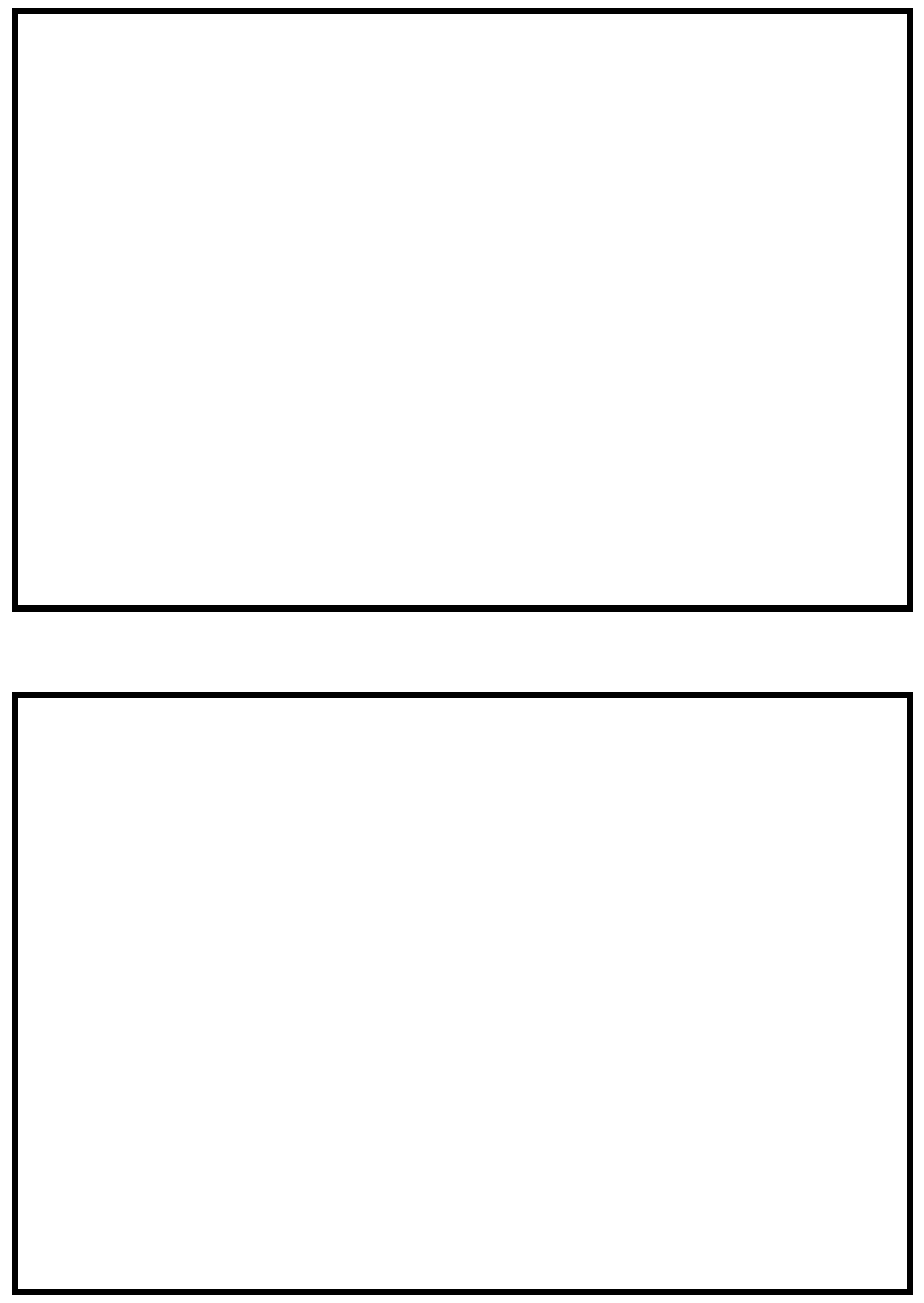

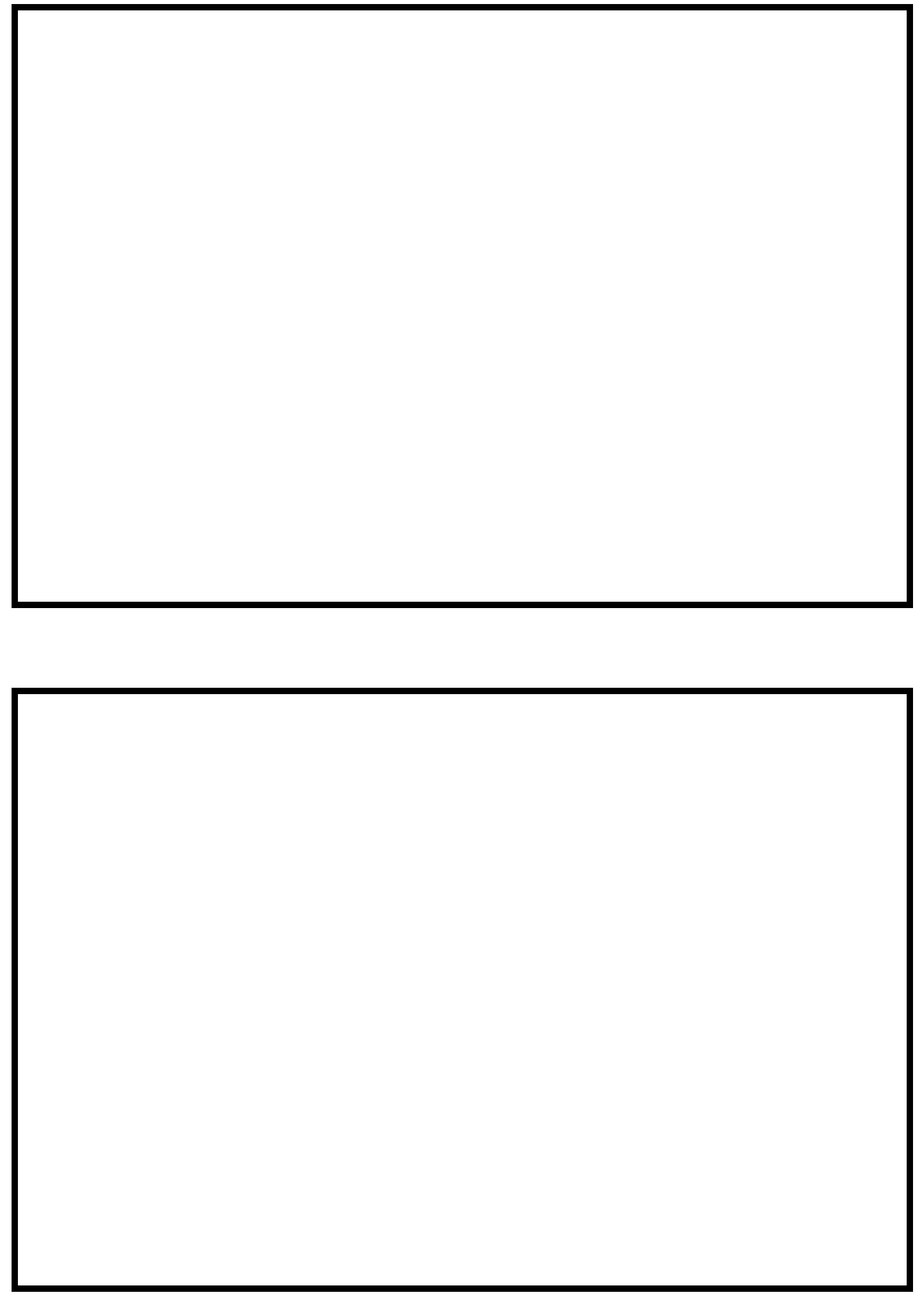


\section{LEVEL II SUMMARY}

\begin{tabular}{llllll} 
Structure Number & CHESTH00060013 & Stream & \multicolumn{2}{l}{ Williams River } \\
& Road & TH 6 & & & \\
County & Windsor & Rict &
\end{tabular}

\section{Description of Bridge}

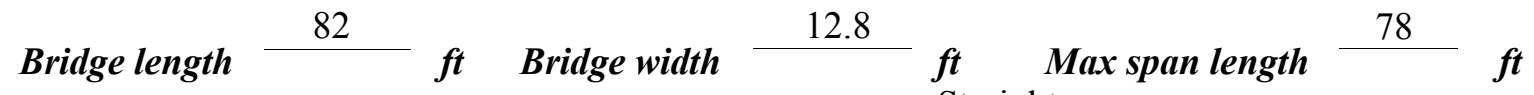
Alignment of bridge to road (on curve or straight)

\begin{tabular}{|c|c|c|c|}
\hline \multirow{2}{*}{ Abutment type } & 1, concrete & \multirow{2}{*}{ Embankment type } & Sloping \\
\hline & Yes & & $8 / 19 / 96$ \\
\hline Stone fill on abutment? & Type-2, & $\begin{array}{l}\text { Dato af incnostinn } \\
\text { ostream and downstrea }\end{array}$ & n ends of the right abutment. \\
\hline
\end{tabular}

Abutments are concrete. There is a two $\mathrm{ft}$ deep scour hole in front of the right abutment.

No

0

No There is

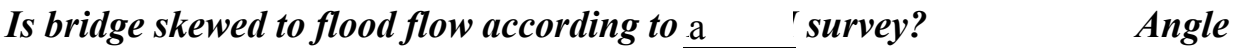

moderate channel bend in the upstream reach.

Debris accumulation on bridge at time of Level I or Level II site visit:

\begin{tabular}{|c|c|c|c|}
\hline & $\begin{array}{c}\text { Date of insnortion } \\
8 / 19 / 96 \\
\end{array}$ & $\begin{array}{l}\text { Percent of almmant } \\
\text { blocked inortzontatly }\end{array}$ & $\begin{array}{l}\text { Percent of } 0 \\
\text { blocked verticatty }\end{array}$ \\
\hline Level I & $8 / 19 / 96$ & 0 & 0 \\
\hline & Low. & & \\
\hline
\end{tabular}

Potential for debris

None as of 8/19/96.

Doscriho any, foaturos noar ar at tho hridoo that mav, affort flou, (includo ahsorvation dato) 


\section{Description of the Geomorphic Setting}

General topography The channel is located within a moderate relief valley with a flat narrow flood plain on the left bank.

Geomorphic conditions at bridge site: downstream (DS), upstream (US)

Date of inspection $\quad 8 / 19 / 96$

DS left: $\quad$ Steep channel bank to a narrow flood plain

DS right: $\quad$ Steep channel bank to the steep valley wall

US left: $\quad$ Steep channel bank to a narrow flood plain

US right: Steep channel bank to the steep valley wall

\section{Description of the Channel}

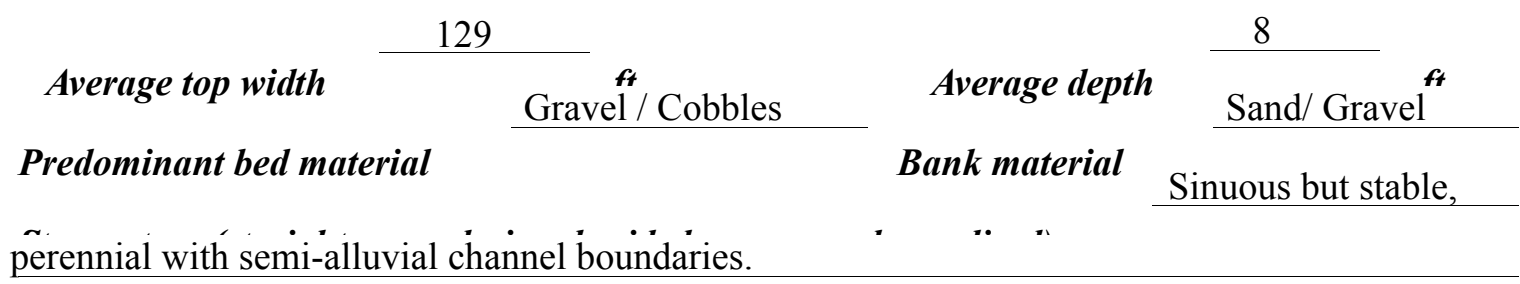

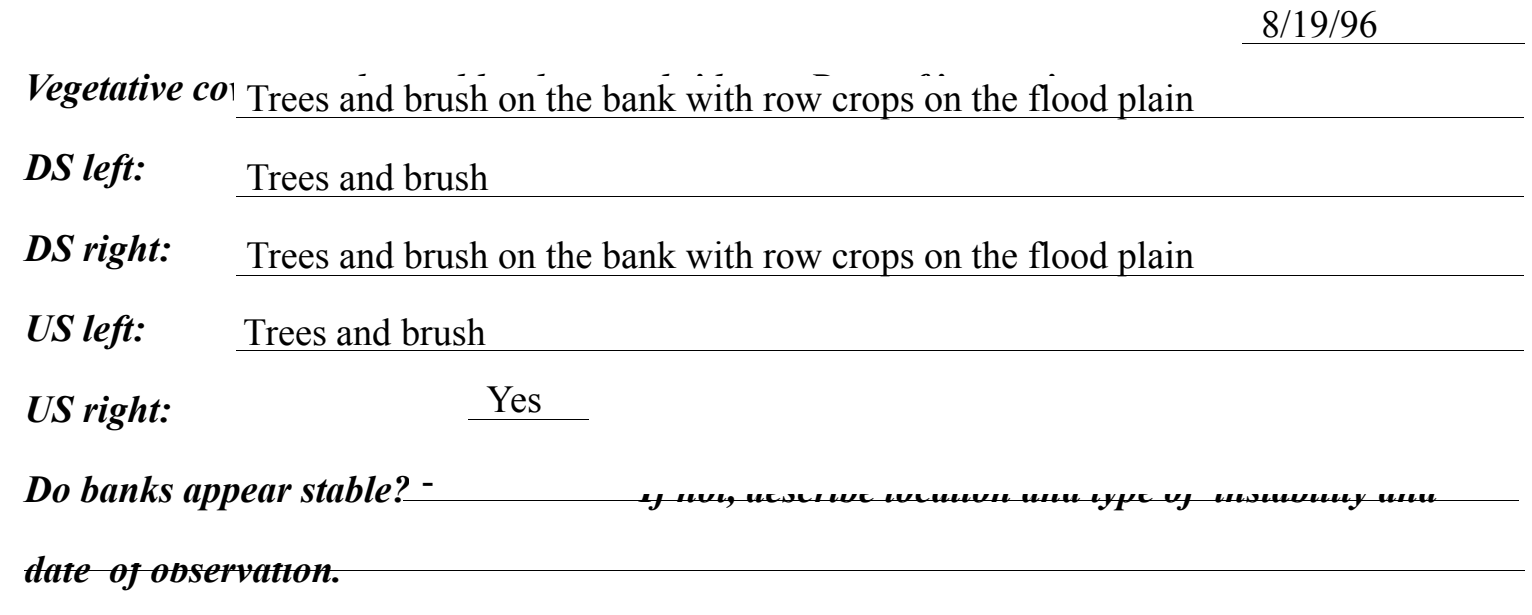

None as of 8/19/96.

Describe any obstructions in channel and date of observation. 


\title{
Hydrology
}

Drainage area $\quad 80.6 \boldsymbol{m i}^{2}$

Percentage of drainage area in physiographic provinces: (approximate)

Physiographic province/section New England/New England Upland
Percent of drainage area 100

\begin{abstract}
Is drainage area considered rural or urban?
Rural None urbanization:-
\end{abstract}

Yes

Is there a USGS gage on the stream of interest? Williams River at Brockways Mills, VT USGS gage description 01153500

USGS gage number 103

Gage drainage area $\quad \mathrm{mi}^{2}$ No

Is there a lake/p -

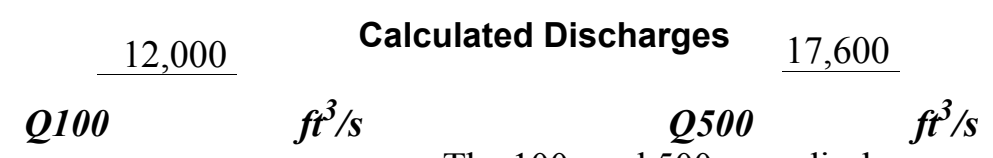

The 100- and 500-year discharges are based on the

hydrologic data for the Williams River above Hall Brook presented in the Flood Insurance Study for Chester, VT (Federal Emergency Management Agency, February 1982). The values used were within a range defined by flood frequency curves developed from several empirical methods (Benson, 1962; Johnson and Tasker, 1974; FHWA, 1983; Potter, 1957a\&b; Talbot, 1887). Each curve was extended graphically to the 500 -year event. 


\section{Description of the Water-Surface Profile Model (WSPRO) Analysis}

Datum for WSPRO analysis (USGS survey, sea level, VTAOT plans)

USGS survey

Datum tie between USGS survey and VTAOT plans

None

Description of reference marks used to determine USGS datum. $\quad$ RM1 is a chiseled X on

top of the downstream end of the right abutment (elev. $498.74 \mathrm{ft}$, arbitrary survey datum). RM2

is a chiseled X on top of the upstream end of the left abutment (elev. $496.11 \mathrm{ft}$, arbitrary survey

datum).

\section{Cross-Sections Used in WSPRO Analysis}

\begin{tabular}{cccl}
\hline${ }^{1}$ Cross-section & $\begin{array}{c}\text { Section } \\
\text { Reference } \\
\text { Distance } \\
(\text { SRD) in feet }\end{array}$ & $\begin{array}{c}{ }^{2} \text { Cross-section } \\
\text { development }\end{array}$ & \multicolumn{1}{c}{ Comments } \\
\hline EXITX & -85 & 5 & $\begin{array}{l}\text { Exit section as surveyed } \\
\text { for the Flood Insurance } \\
\text { Study (February 1982) }\end{array}$ \\
FULLV & 0 & 2 & $\begin{array}{l}\text { Downstream Full-valley } \\
\text { section (Templated from } \\
\text { EXITX) }\end{array}$ \\
RDIDG & 0 & 1 & $\begin{array}{l}\text { Bridge section } \\
\text { Road Grade section }\end{array}$ \\
APPRO & 9 & 1 & Approach section \\
\hline
\end{tabular}

${ }^{1}$ For location of cross-sections see plan-view sketch included with Level I field form, Appendix E. For more detail on how cross-sections were developed see WSPRO input file. 


\section{Data and Assumptions Used in WSPRO Model}

Hydraulic analyses of the reach were done by use of the Federal Highway Administration's WSPRO step-backwater computer program (Shearman and others, 1986, and Shearman, 1990). The analyses reported herein reflect conditions existing at the site at the time of the study. Furthermore, in the development of the model it was necessary to assume no accumulation of debris or ice at the site. Results of the hydraulic model are presented in the Bridge Hydraulic Summary, appendix B, and figure 7.

Channel roughness factors (Manning's " $n$ ") used in the hydraulic model were estimated using field inspections at each cross section following the general guidelines described by Arcement and Schneider (1989). Final adjustments to the values were made during the modelling of the reach. Channel " $n$ " values for the reach ranged from 0.050 to 0.051 , and overbank " $n$ " values ranged from 0.040 to 0.070 .

Normal depth at the exit section (EXITX) was based on a known water surface. The starting water surface was from the profile plot in the Flood Insurance Study for Chester, VT (Federal Emergency Management Agency, February 1982).

The approach section (APPRO) was surveyed one bridge length upstream of the upstream face as recommended by Shearman and others (1986). This location provides a consistent method for determining scour variables.

For the 500-year discharge, the roadway wier is submerged. The WSPRO bridge routines failed to find a solution which balanced the total discharge and energy at the APPRO section with the sum of the discharges and energy over the roadway and through the bridge opening. Therefore, the bridge deck was removed from the section, and the channel underneath the bridge was combined with the roadway cross-section to represent a full-valley cross-section at the bridge location. 


\section{Bridge Hydraulics Summary}

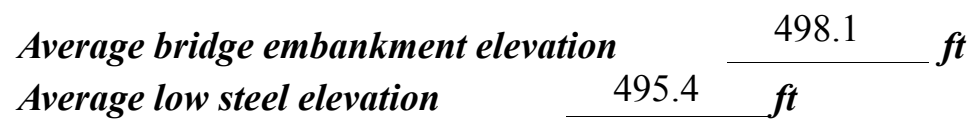

$$
\text { 100-year discharge } \quad 12,000 \quad \mathrm{ft}^{3} / \mathrm{s}
$$

Water-surface elevation in bridge opening $\quad 491.1 \quad f t$

Road overtopping? ___ Yes Discharge over road _ـ 3,780 $\boldsymbol{f t}^{3} / \mathrm{s}$

\begin{tabular}{llll} 
Area of flow in bridge opening & 902 & $\boldsymbol{f t}^{2}$ & \\
\cline { 2 - 3 } Average velocity in bridge opening & 9.1 & $\mathrm{ft} / \mathrm{s}$
\end{tabular}

Maximum WSPRO tube velocity at bridge $11.4 \mathrm{ft} / \mathrm{s}$

Water-surface elevation at Approach section with bridge 492.9

Water-surface elevation at Approach section without bridge $\quad 492.1$

Amount of backwater caused by bridge $\quad 0.8$ it

500-year discharge $\quad 17,600 \quad \mathrm{ft}^{3} / \mathrm{s}$

Water-surface elevation in bridge opening $\quad 494.5 \mathrm{ft}$

Road overtopping? ___ Yes Discharge over road _ $\quad 6,670 \mathrm{ft}^{3} / \mathrm{s}$

\begin{tabular}{llll} 
Area of flow in bridge opening & 1153 & $\boldsymbol{f t}^{2}$ & \\
\cline { 2 - 3 } Average velocity in bridge opening & 9.5 & $\mathrm{ft} / \mathrm{s}$
\end{tabular}

Maximum WSPRO tube velocity at bridge 12.2 's

Water-surface elevation at Approach section with bridge

Water-surface elevation at Approach section without bridge

Amount of backwater caused by bridge N/A ,t

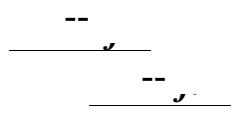

Incipient overtopping discharge $\quad 10,000 \mathrm{ft}^{3} / \mathrm{s}$

Water-surface elevation in bridge opening $488.7 \quad$ t

Area of flow in bridge opening $\quad 724 \quad \mathrm{ft}^{2}$

Average velocity in bridge opening $\quad 13.8 \quad \mathrm{ft} / \mathrm{s}$

Maximum WSPRO tube velocity at bridge $\quad 17.0 \mathrm{ft} / \mathrm{s}$

Water-surface elevation at Approach section with bridge

Water-surface elevation at Approach section without bridge

492.2

Amount of backwater caused by bridge $\quad 1.1$, t

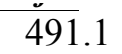




\section{Scour Analysis Summary}

\section{Special Conditions or Assumptions Made in Scour Analysis}

Scour depths were computed using the general guidelines described in Hydraulic Engineering Circular 18 (Richardson and Davis, 1995). Scour depths were calculated assuming an infinite depth of erosive material and a homogeneous particle-size distribution. The results of the scour analyses for the 100- and 500-year discharges are presented in tables 1 and 2 and the scour depths are shown graphically in figure 8 .

Contraction scour for the 100-year, 500-year, and incipient roadway-overtopping discharges was computed by use of the Laursen clear-water contraction scour equation (Richardson and Davis, 1995, p. 32, equation 20). The streambed armoring depths computed suggest that armoring will not limit the depth of contraction scour.

Abutment scour for the right abutment was computed by use of the Froehlich equation (Richardson and Davis, 1995, p. 48, equation 28). Variables for the Froehlich equation include the Froude number of the flow approaching the embankments, the length of the embankment blocking flow, and the depth of flow approaching the embankment less any roadway overtopping.

Scour at the left abutment was computed by use of the HIRE equation (Richardson and Davis, 1995, p. 49, equation 29) because the HIRE equation is recommended when the length to depth ratio of the embankment blocking flow exceeds 25 . The variables used by the HIRE abutment-scour equation are defined the same as those defined for the Froehlich abutment-scour equation. 


\section{Scour Results}

Contraction scour:

Main channel

Live-bed scour

Clear-water scour

Depth to armoring

Left overbank

Right overbank

Local scour:

Abutment scour

Left abutment

Right abutment

Pier scour

Pier 1

Pier 2

Pier 3 100-year discharge
Incipient

500-year overtopping discharge discharge

(Scour depths in feet)

\begin{tabular}{|c|c|c|}
\hline-- & -- & -- \\
\hline 0.0 & 0.0 & 0.9 \\
\hline $1.1^{-}$ & $1.0^{-}$ & $14.8^{-}$ \\
\hline$--^{-}$ & -- & $--^{-}$ \\
\hline--- & --- & --- \\
\hline
\end{tabular}

5.0

24.9-
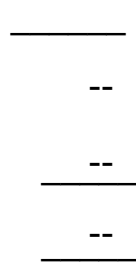

8.4

26.8
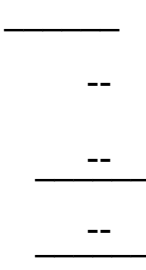

7.4

25.6-

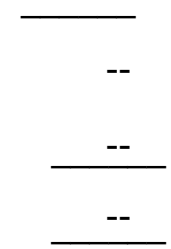

\section{Riprap Sizing}

Abutments:

Left abutment

Right abutment

Piers:

Pier 1

Pier 2

\section{0-year discharge}

$$
2.4
$$

2.4
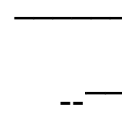

--
Incipient

500-year discharge (D $D_{50}$ in feet)

1.8

1.8

4.2
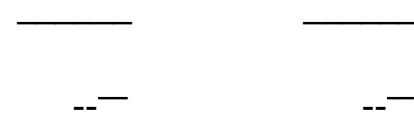

overtopping discharge

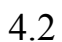

\section{2}

洒
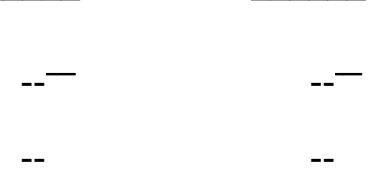

-- 


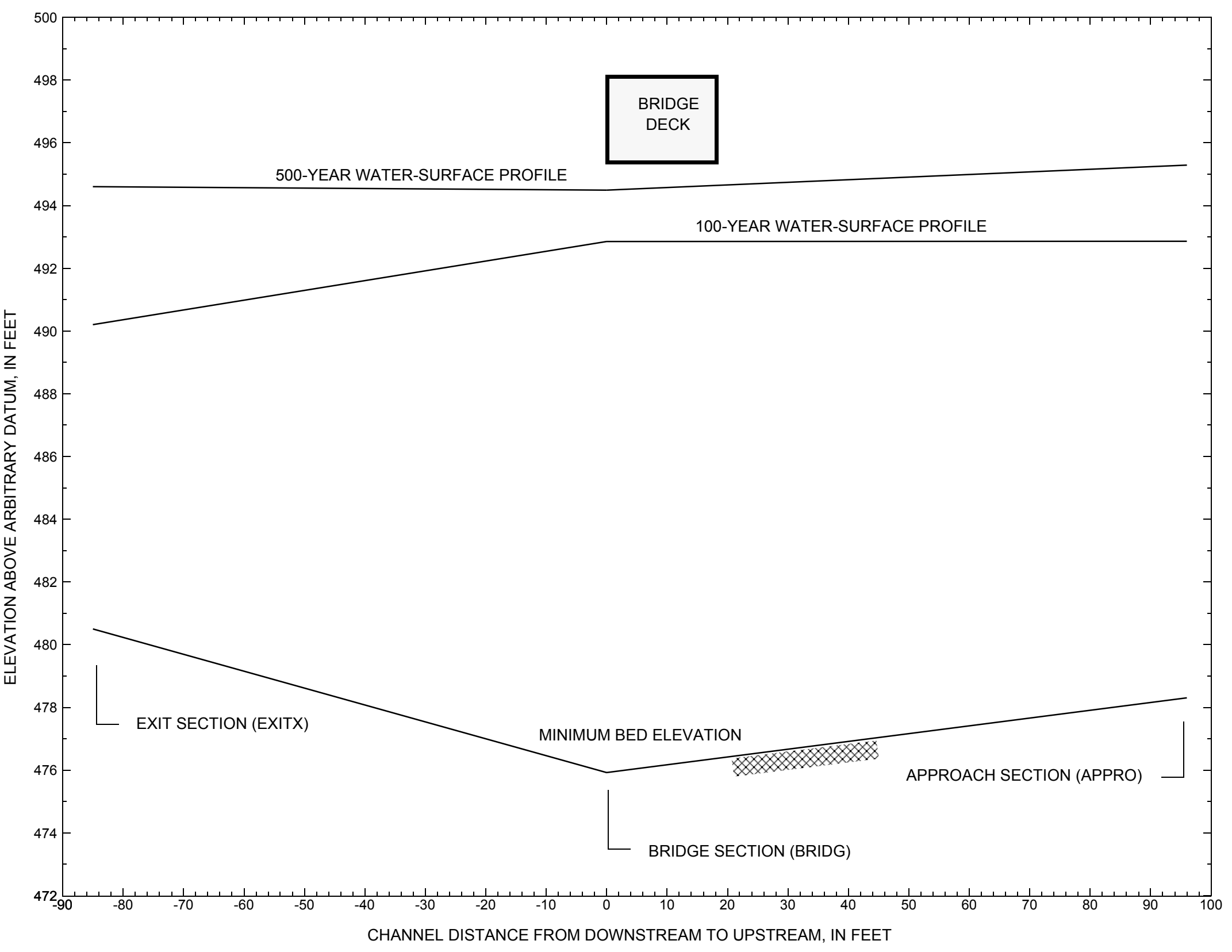

Figure 7. Water-surface profiles for the 100- and 500-year discharges at structure CHESTH00060013 on Town Highway 6, crossing the Williams River, Chester, Vermont. 


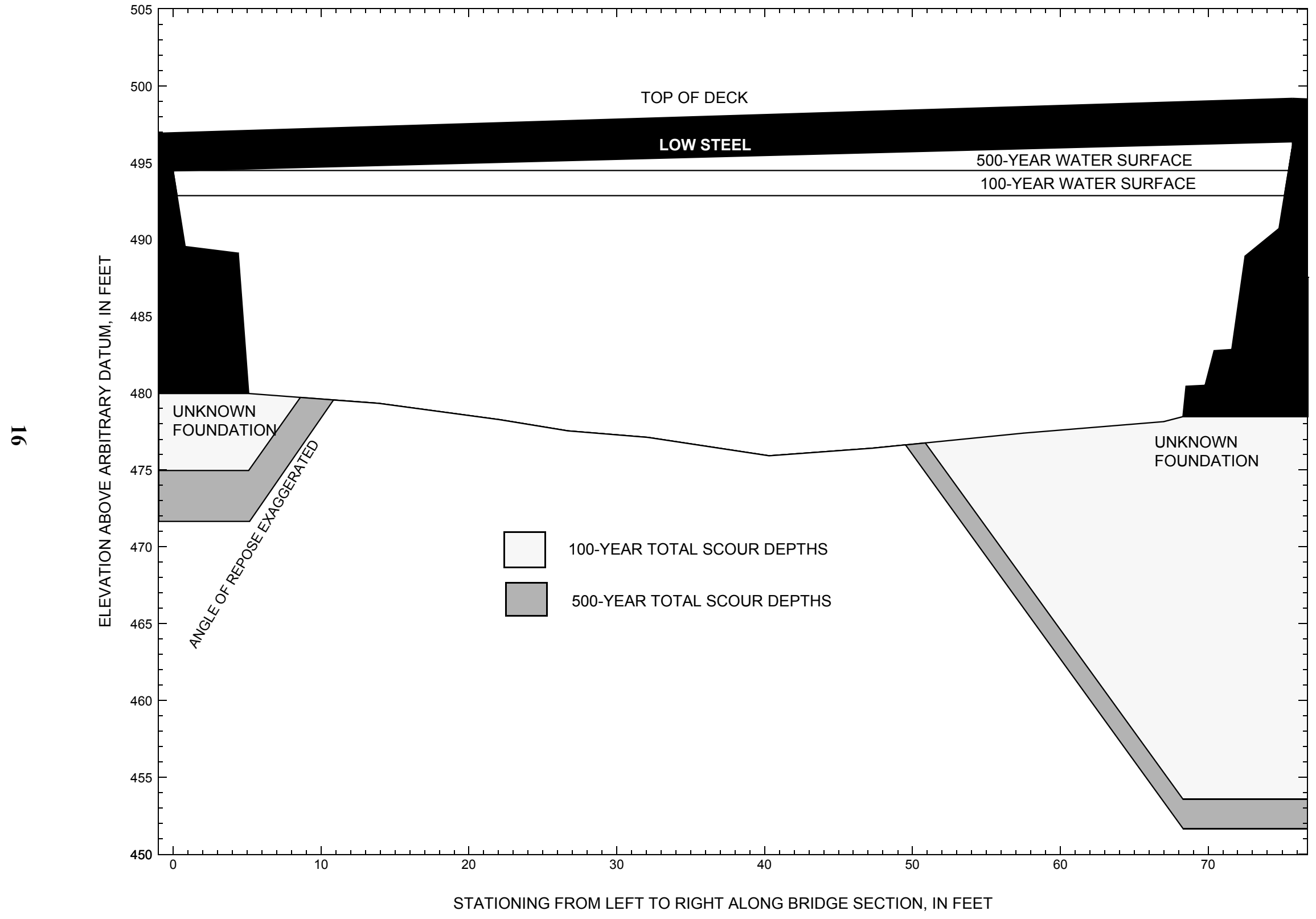

Figure 8. Scour elevations for the 100- and 500-year discharges at structure CHESTH00060013 on Town Highway 6, crossing the Williams River, Chester, Vermont. 
Table 1. Remaining footing/pile depth at abutments for the 100-year discharge at structure CHESTH00060013 on Town Highway 6, crossing the Williams River, Chester, Vermont.

[VTAOT, Vermont Agency of Transportation; --, no data]

\begin{tabular}{|c|c|c|c|c|c|c|c|c|c|c|c|}
\hline Description & Station $^{1}$ & $\begin{array}{l}\text { VTAOT } \\
\text { minimum } \\
\text { low-chord } \\
\text { elevation } \\
\text { (feet) }\end{array}$ & $\begin{array}{l}\text { Surveyed } \\
\text { minimum } \\
\text { low-chord } \\
\text { elevation } \\
\text { (feet) }\end{array}$ & $\begin{array}{c}\text { Bottom of } \\
\text { footing/pile } \\
\text { elevation }{ }^{2} \\
\text { (feet) }\end{array}$ & $\begin{array}{l}\text { Channel } \\
\text { elevation at } \\
\text { abutment/ } \\
\text { pier }^{2} \\
\text { (feet) }\end{array}$ & $\begin{array}{l}\text { Contraction } \\
\text { scour depth } \\
\text { (feet) }\end{array}$ & $\begin{array}{l}\text { Abutment } \\
\text { scour } \\
\text { depth } \\
\text { (feet) }\end{array}$ & $\begin{array}{l}\text { Pier } \\
\text { scour } \\
\text { depth } \\
\text { (feet) }\end{array}$ & $\begin{array}{l}\text { Depth of } \\
\text { total scour } \\
\text { (feet) }\end{array}$ & $\begin{array}{c}\text { Elevation of } \\
\text { scour }^{2} \\
\text { (feet) }\end{array}$ & $\begin{array}{c}\text { Remaining } \\
\text { footing/pile } \\
\text { depth } \\
\text { (feet) }\end{array}$ \\
\hline \multicolumn{12}{|c|}{100 -year discharge is 12,000 cubic-feet per second } \\
\hline Left abutment & 0.0 & -- & 494.5 & -- & 480.0 & 0.0 & 5.0 & -- & 5.0 & 475.0 & -- \\
\hline Right abutment & 75.7 & -- & 496.4 & -- & 478.5 & 0.0 & 24.9 & -- & 24.9 & 453.6 & -- \\
\hline
\end{tabular}

1.Measured along the face of the most constricting side of the bridge.

2.Arbitrary datum for this study.

Table 2. Remaining footing/pile depth at abutments for the 500-year discharge at structure CHESTH00060013 on Town Highway 6, crossing the Williams River, Chester, Vermont.

[VTAOT, Vermont Agency of Transportation; --, no data]

\begin{tabular}{|c|c|c|c|c|c|c|c|c|c|c|c|}
\hline Description & Station $^{1}$ & $\begin{array}{l}\text { VTAOT } \\
\text { minimum } \\
\text { low-chord } \\
\text { elevation } \\
\text { (feet) }\end{array}$ & $\begin{array}{c}\text { Surveyed } \\
\text { minimum } \\
\text { low-chord } \\
\text { elevation } \\
\text { (feet) }\end{array}$ & $\begin{array}{c}\text { Bottom of } \\
\text { footing/pile } \\
\text { elevation } \\
\text { (feet) }\end{array}$ & $\begin{array}{c}\text { Channel } \\
\text { elevation at } \\
\text { abutment/ } \\
\text { pier }^{2} \\
\text { (feet) }\end{array}$ & $\begin{array}{l}\text { Contraction } \\
\text { scour depth } \\
\text { (feet) }\end{array}$ & $\begin{array}{c}\text { Abutment } \\
\text { scour } \\
\text { depth } \\
\text { (feet) }\end{array}$ & $\begin{array}{l}\text { Pier } \\
\text { scour } \\
\text { depth } \\
\text { (feet) }\end{array}$ & $\begin{array}{l}\text { Depth of } \\
\text { total scour } \\
\text { (feet) }\end{array}$ & $\begin{array}{c}\text { Elevation of } \\
\text { scour }^{2} \\
\text { (feet) }\end{array}$ & $\begin{array}{c}\text { Remaining } \\
\text { footing/pile } \\
\text { depth } \\
\text { (feet) }\end{array}$ \\
\hline \multicolumn{12}{|c|}{500 -year discharge is 17,600 cubic-feet per second } \\
\hline Left abutment & 0.0 & -- & 494.5 & -- & 480.0 & 0.0 & 8.2 & -- & 8.2 & 471.8 & -- \\
\hline Right abutment & 75.7 & -- & 496.4 & -- & 478.5 & 0.0 & 26.8 & -- & 26.8 & 451.7 & -- \\
\hline
\end{tabular}

1.Measured along the face of the most constricting side of the bridge.

2.Arbitrary datum for this study. 


\section{SELECTED REFERENCES}

Arcement, G.J., Jr., and Schneider, V.R., 1989, Guide for selecting Manning's roughness coefficients for natural channels and flood plains:

U.S. Geological Survey Water-Supply Paper 2339, 38 p.

Barnes, H.H., Jr., 1967, Roughness characteristics of natural channels: U.S. Geological Survey Water-Supply Paper 1849,213 p.

Benson, M. A., 1962, Factors Influencing the Occurrence of Floods in a Humid Region of Diverse Terrain: U.S. Geological Survey WaterSupply Paper 1580-B, 64 p.

Brown, S.A. and Clyde, E.S., 1989, Design of riprap revetment: Federal Highway Administration Hydraulic Engineering Circular No. 11, Publication FHWA-IP-89-016, 156 p.

Federal Emergency Management Agency, 1982, Flood Insurance Study, Town of Chester, Windsor County, Vermont: Washington, D.C., February 1982.

Federal Highway Administration, 1983, Runoff estimates for small watersheds and development of sound design: Federal Highway Administration Report FHWA-RD-77-158.

Federal Highway Administration, 1993, Stream Stability and Scour at Highway Bridges: Participant Workbook: Federal Highway Administration Report FHWA-HI-91-011.

Froehlich, D.C., 1989, Local scour at bridge abutments in Ports, M.A., ed., Hydraulic Engineering--Proceedings of the 1989 National Conference on Hydraulic Engineering: New York, American Society of Civil Engineers, p. 13-18.

Hayes, D.C.,1993, Site selection and collection of bridge-scour data in Delaware, Maryland, and Virginia: U.S. Geological Survey WaterResources Investigation Report 93-4017, 23 p.

Interagency Advisory Committee on Water Data, 1982, Guidelines for determining flood flow frequency: U.S. Geological Survey, Bulletin 17B of the Hydrology Subcommittee, 190 p.

Johnson, C.G. and Tasker, G.D.,1974, Progress report on flood magnitude and frequency of Vermont streams: U.S. Geological Survey OpenFile Report 74-130, 37 p.

Lagasse, P.F., Schall, J.D., Johnson, F., Richardson, E.V., Chang, F., 1995, Stream Stability at Highway Structures: Federal Highway Administration Hydraulic Engineering Circular No. 20, Publication FHWA-IP-90-014, 144 p.

Laursen, E.M., 1960, Scour at bridge crossings: Journal of the Hydraulics Division, American Society of Civil Engineers, v. 86, no. HY2, p. 39-53.

Potter, W. D., 1957a, Peak rates of runoff in the Adirondack, White Mountains, and Maine woods area, Bureau of Public Roads

Potter, W. D., 1957b, Peak rates of runoff in the New England Hill and Lowland area, Bureau of Public Roads

Richardson, E.V. and Davis, S.R., 1995, Evaluating scour at bridges: Federal Highway Administration Hydraulic Engineering Circular No. 18, Publication FHWA-IP-90-017, 204 p.

Richardson, E.V., Simons, D.B., and Julien, P.Y., 1990, Highways in the river environment: Federal Highway Administration Publication FHWA-HI-90-016.

Ritter, D.F., 1984, Process Geomorphology: W.C. Brown Co., Debuque, Iowa, 603 p.

Shearman, J.O., 1990, User's manual for WSPRO--a computer model for water surface profile computations: Federal Highway Administration Publication FHWA-IP-89-027, 187 p.

Shearman, J.O., Kirby, W.H., Schneider, V.R., and Flippo, H.N., 1986, Bridge waterways analysis model; research report: Federal Highway Administration Publication FHWA-RD-86-108, 112 p.

Talbot, A.N., 1887, The determination of water-way for bridges and culverts.

U.S. Geological Survey, 1984, Saxtons River, Vermont 7.5 X 15 Minute Series quadrangle map: U.S. Geological Survey Topographic Maps, Scale 1:25,000. 


\section{APPENDIX A: \\ WSPRO INPUT FILE}




\section{WSPRO INPUT FILE}

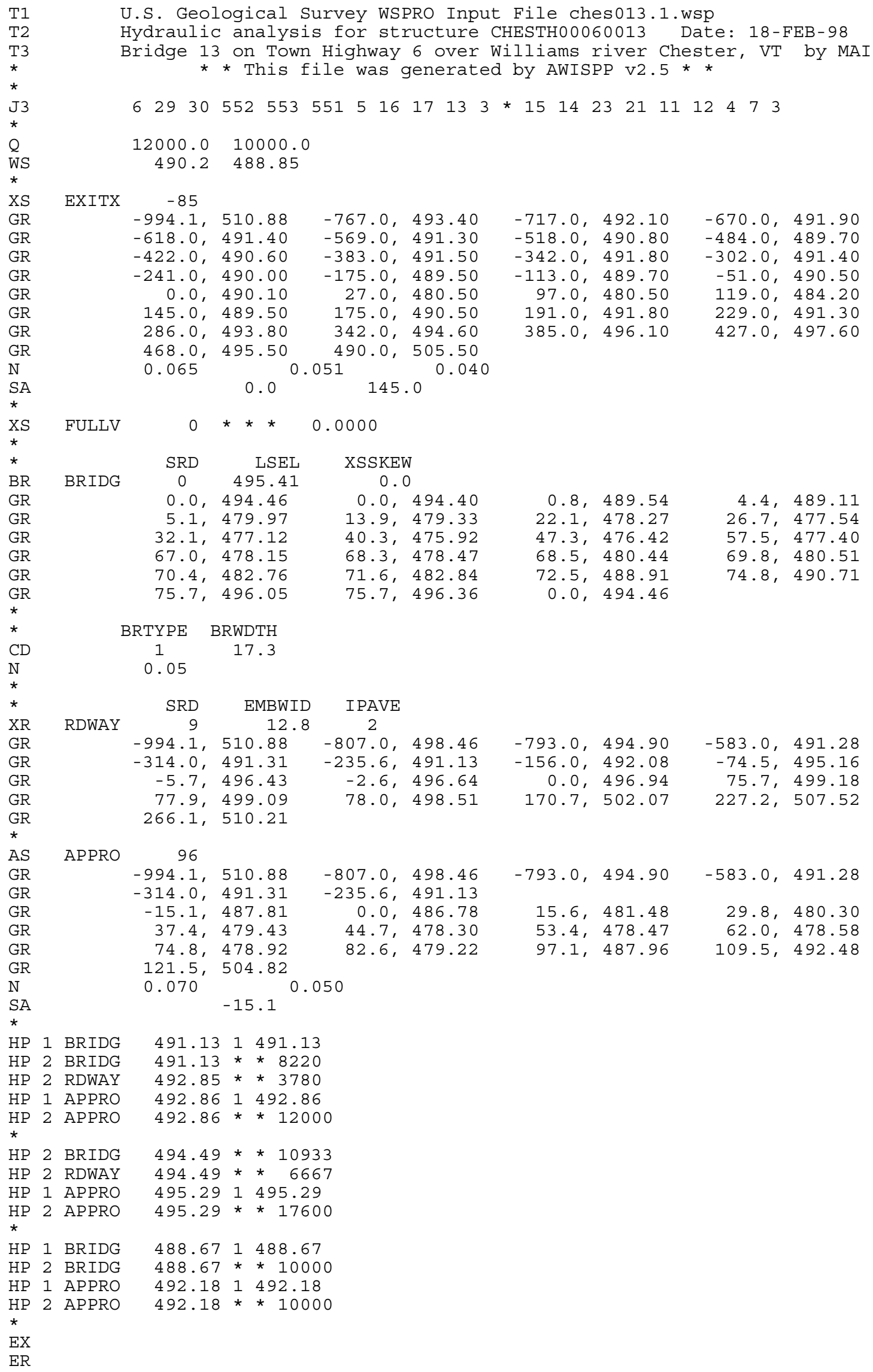




\section{WSPRO INPUT FILE (continued)}

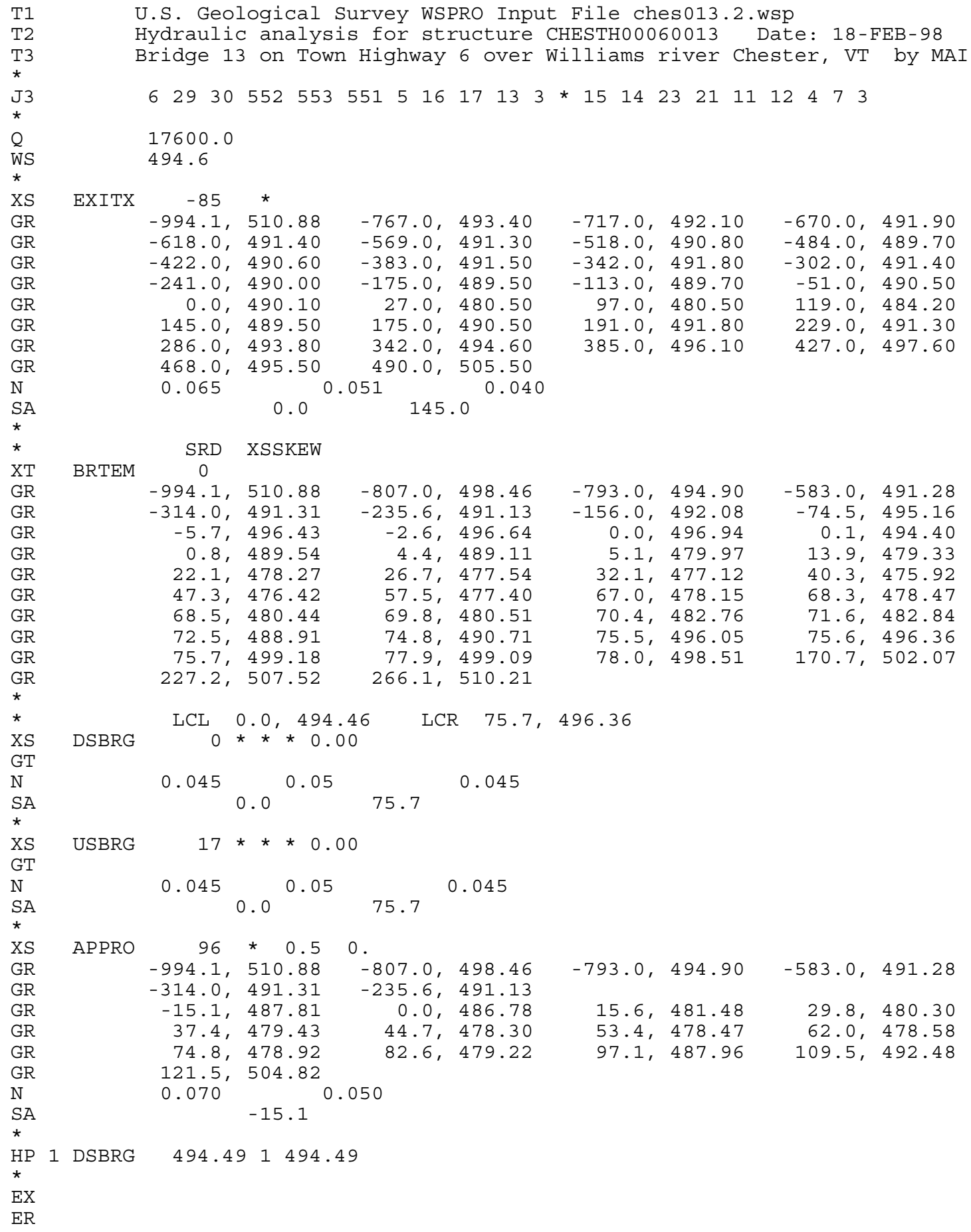




\section{APPENDIX B: \\ WSPRO OUTPUT FILE}




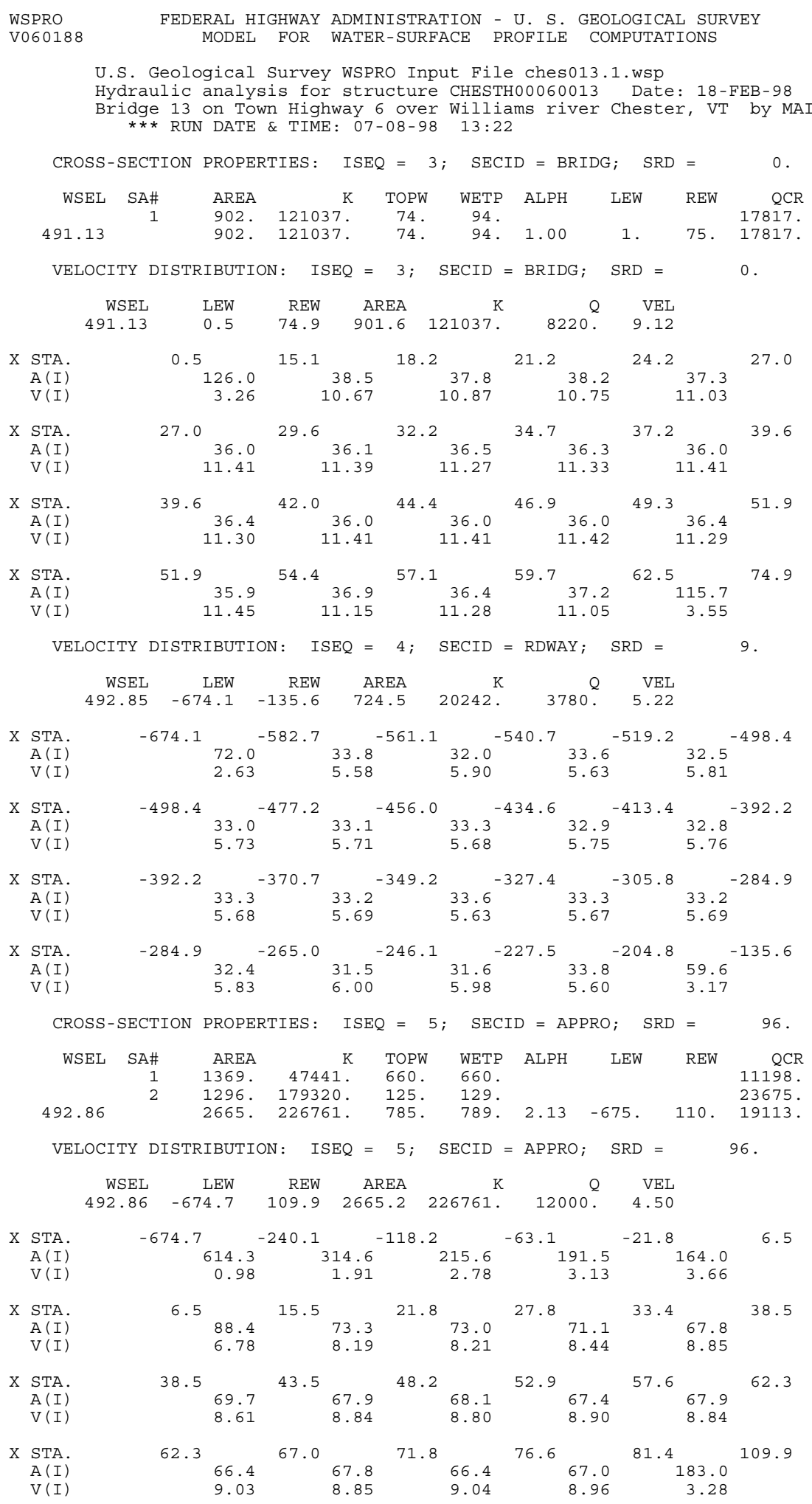




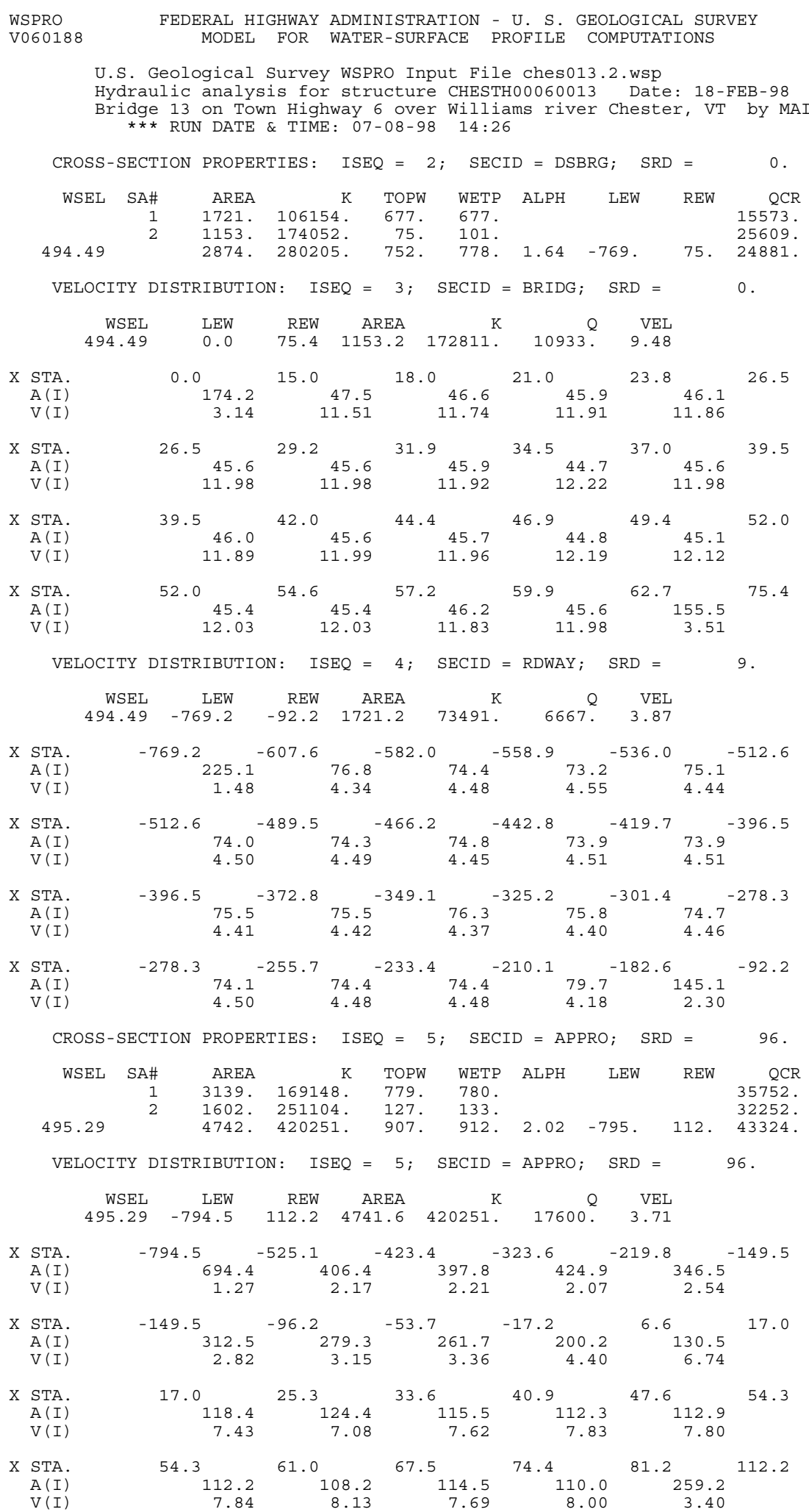


WSPRO OUTPUT FILE (continued)

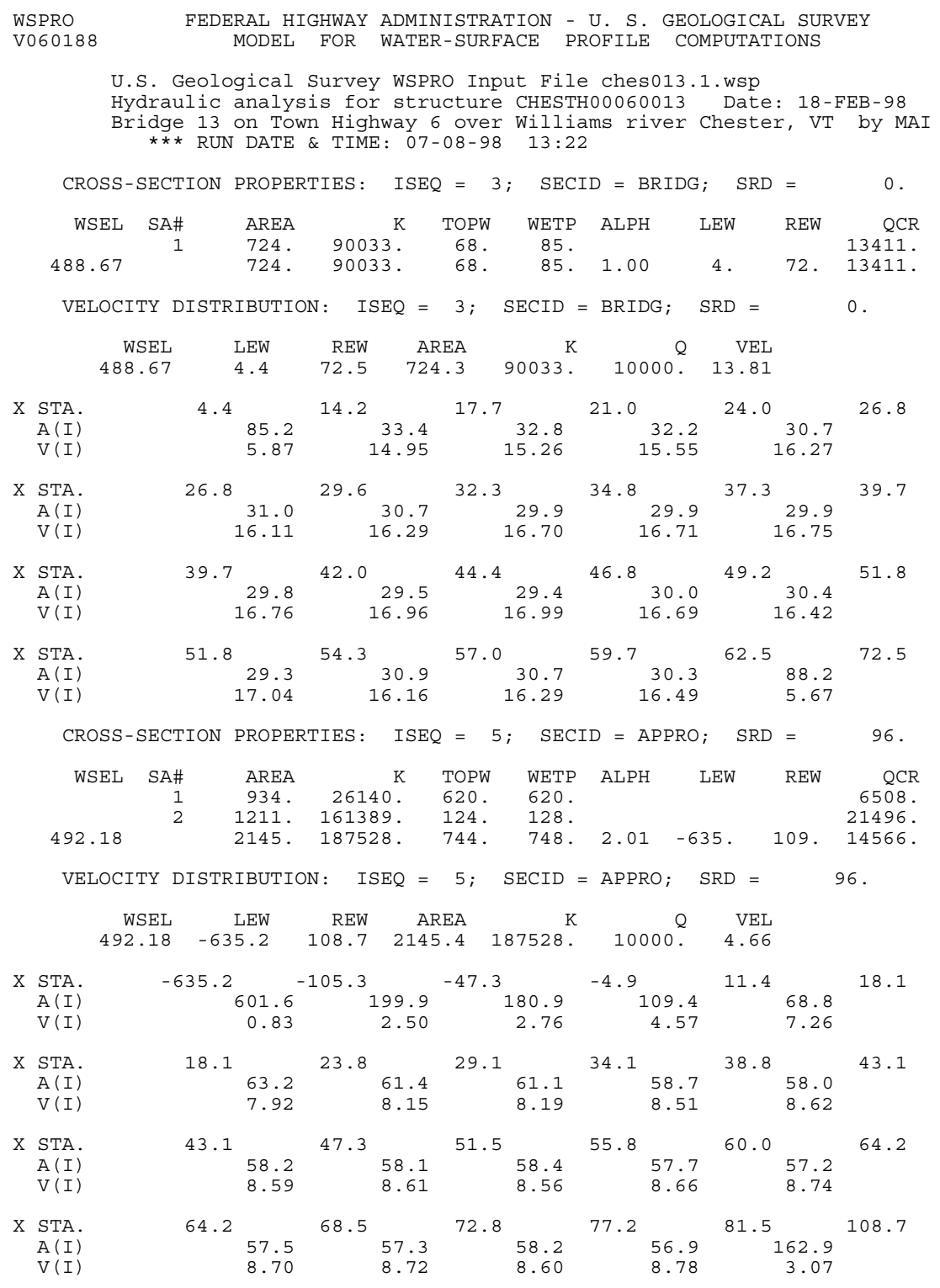


WSPRO OUTPUT FILE (continued)

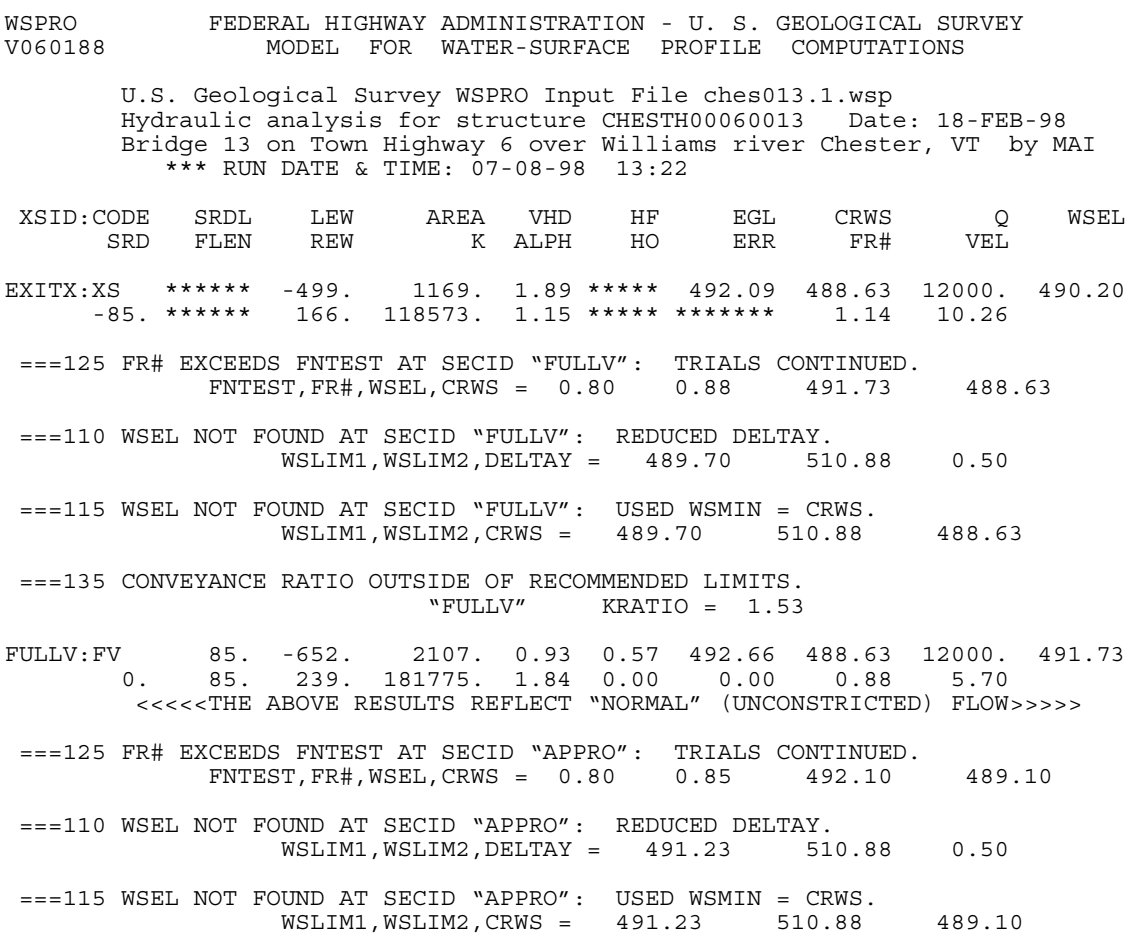

FIRST USER DEFINED TABLE.

\begin{tabular}{|c|c|c|c|c|c|c|c|c|}
\hline XSID : CODE & SRD & LEW & REW & $\mathrm{Q}$ & $\mathrm{K}$ & AREA & VEL & WSEL \\
\hline EXITX:XS & -85 . & -499 . & 166. & 12000 . & 118573. & 1169. & 10.26 & 490.20 \\
\hline FULLV : FV & 0 & -652 . & 239. & 12000. & 181775. & 2107. & 5.70 & 491.73 \\
\hline BRIDG : BR & 0. & 1. & 75 . & 8220 & 121051. & 902 . & 9.12 & 491.13 \\
\hline RDWAY : RG & 9. & $\star * \star \star * * *$ & 3780 . & 3780. & $\star \star \star \star * \star * \star * *$ & 0 & 2.00 & 492.85 \\
\hline APPRO : AS & 96. & -674 & 110 . & 12000. & 226544 . & 2662 . & 4.51 & 492.86 \\
\hline XSID : CODE & XLKQ & XRKQ & & & & & & \\
\hline APPRO: AS & 5. & 79. & 15665 & & & & & \\
\hline
\end{tabular}

SECOND USER DEFINED TABLE.

\begin{tabular}{|c|c|c|c|c|c|c|c|c|c|}
\hline XSID: CODE & CRWS & FR\# & YMIN & YMAX & $\mathrm{HF}$ & $\mathrm{HO}$ & VHD & EGL & WSE \\
\hline EXITX:XS & 488.63 & 1.14 & 480.50 & 510.88 * & $* \star * \star * \star * \star$ & $* \star * * *$ & 1.89 & 492.09 & 490 \\
\hline FULLV : FV & 488.63 & 0.88 & 480.50 & 510.88 & 0.57 & 0.00 & 0.93 & 492.66 & \\
\hline BRI & & .57 & 22 & & 0.61 & 0.40 & & 10 & 27 \\
\hline RDW & $\star \star \star \star * * * * * * * *$ & $\star * \star * *$ & 91.13 & 10.88 & $0.23 * *$ & $* \star \star \star * *$ & 0.68 & 493.29 & 197 \\
\hline APPRO: AS & 489.10 & 0.63 & 478.30 & 510.88 & 0.35 & 0.08 & 0.67 & 493.53 & 492 \\
\hline
\end{tabular}


WSPRO OUTPUT FILE (continued)

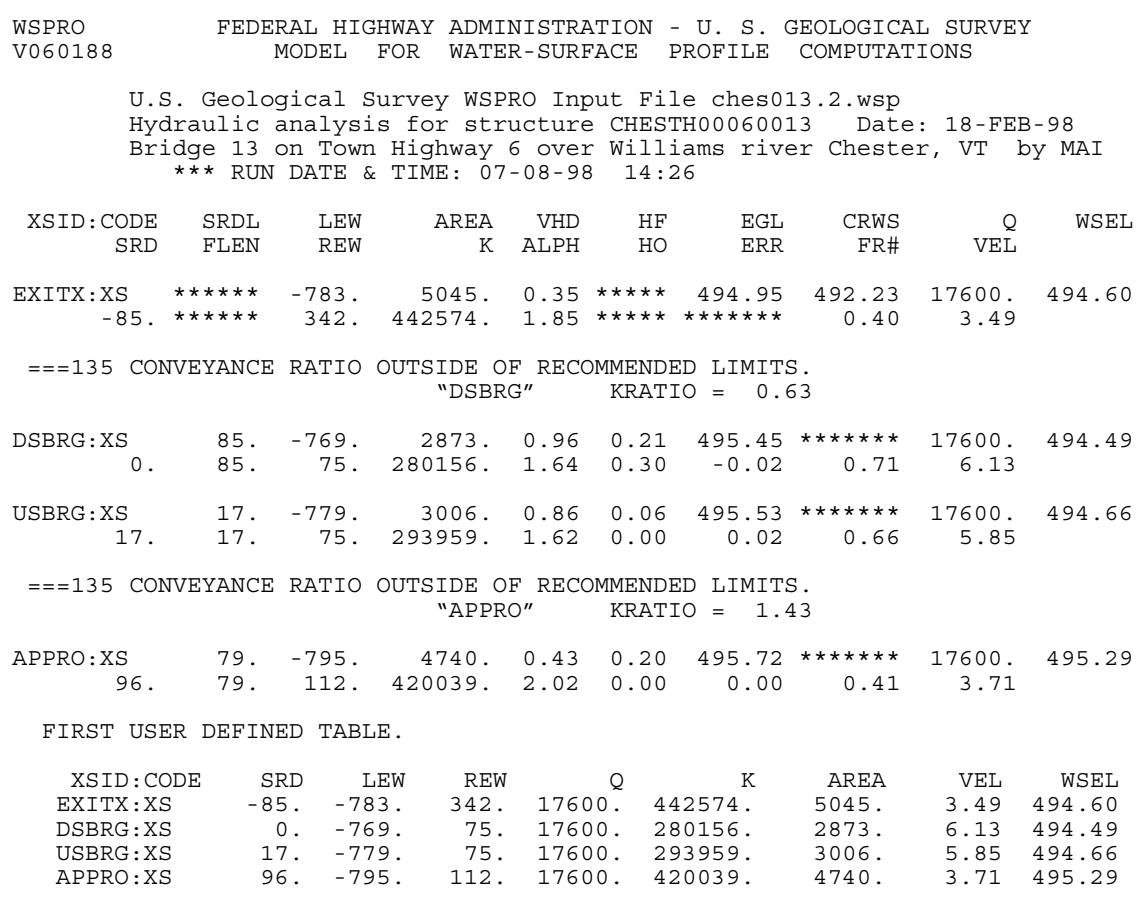

SECOND USER DEFINED TABLE.

$\begin{array}{lrrrrrrrrr}\text { XSID:CODE } & \text { CRWS } & \text { FR\# } & \text { YMIN } & \text { YMAX } & \text { HF } & \text { HO } & \text { VHD } & \text { EGL } & \text { WSEL } \\ \text { EXITX:XS } & 492.23 & 0.40 & 480.50 & 510.88 * * * * * * * * * * * & 0.35 & 494.95 & 494.60 \\ \text { DSBRG:XS } & * * * * * * * * & 0.71 & 475.92 & 510.88 & 0.21 & 0.30 & 0.96 & 495.45 & 494.49 \\ \text { USBRG:XS } & * * * * * * * * & 0.66 & 475.92 & 510.88 & 0.06 & 0.00 & 0.86 & 495.53 & 494.66 \\ \text { APPRO:XS } & * * * * * * * * & 0.41 & 478.30 & 510.88 & 0.20 & 0.00 & 0.43 & 495.72 & 495.29 \\ \text { ER } & & & & & & & & \end{array}$


WSPRO OUTPUT FILE (continued)

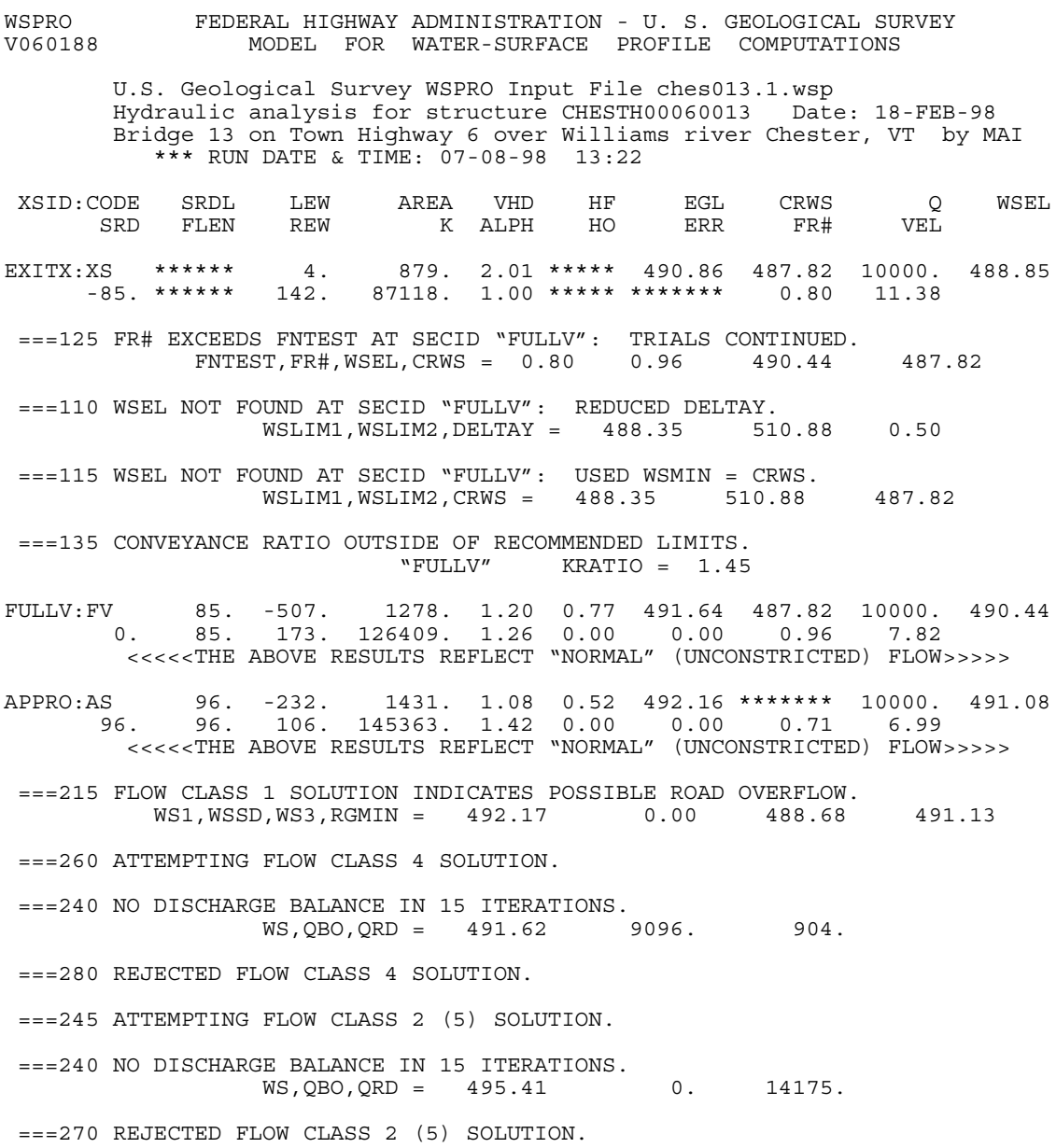




\section{APPENDIX C:}

\section{BED-MATERIAL PARTICLE-SIZE DISTRIBUTION}




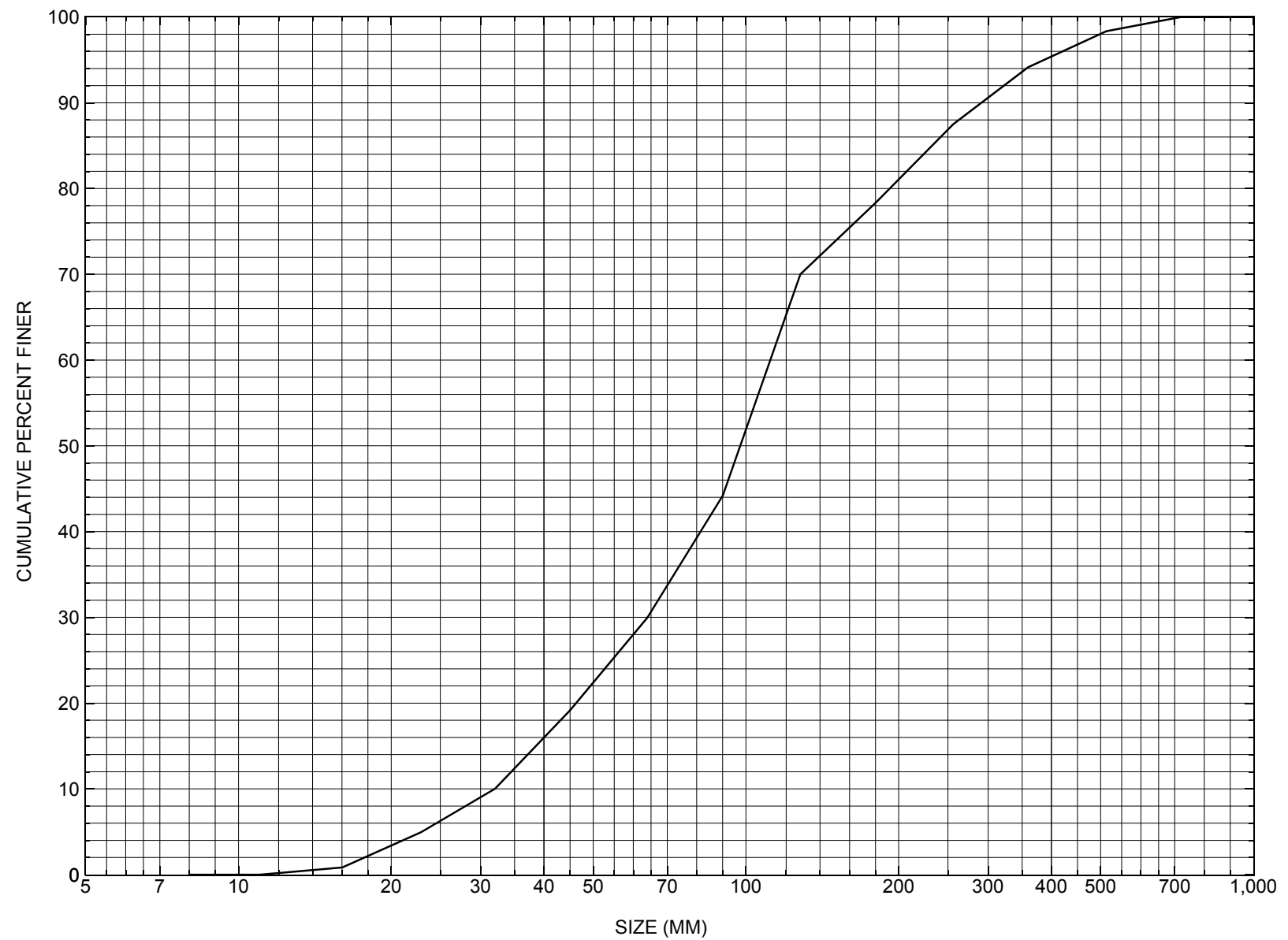

Appendix C. Bed material particle-size distribution for a pebble count in the channel approach of structure CHESTH00060013, in Chester, Vermont. 


\section{APPENDIX D: \\ HISTORICAL DATA FORM}




\section{Structure Number CHESTH00060013}

\section{General Location Descriptive}

Data collected by (First Initial, Full last name) $\mathbf{M}$. Ivanoff

Date $(M M / D D / Y Y) \_\mathbf{0 4} / \underline{05} / \underline{95}$

Highway District Number (I - 2; nn) $\mathbf{0 2}$

Town (FIPS place code; I - 4; nnnnn) 13675

Waterway (I - 6) Williams River

Route Number $\underline{\text { TH006 }}$

Topographic Map Sextons River

Latitude (I - 16; nnnn.n) $\mathbf{4 3 1 4 4}$
County (FIPS county code; I - 3; nnn)

Mile marker (I - 11; nnn.nnn) $\mathbf{0 0 0 0 0 0}$

Road Name (I - 7): -

Vicinity $(I-9) \quad 0.3$ miles to jet with VT 103

Hydrologic Unit Code: $\mathbf{0 1 0 8 0 1 0 7}$

Longitude (i - 17; nnnnn.n) $\mathbf{7 2 3 3 3}$

\section{Select Federal Inventory Codes}

FHWA Structure Number $(I$ - 8) 10140700131407

Maintenance responsibility $(I-21 ; n n) \quad \mathbf{0 3}$

Year built (I - 27; YYYY) 1960

Average daily traffic, ADT (I - 29; nnnnnn) 000030

Year of ADT (I - 30; YY) $\mathbf{9 1}$

Opening skew to Roadway $(I-34 ; n n) \quad \mathbf{0 0}$

Operational status $(I-41 ; X) \underline{\mathbf{A}}$

Structure type (I - 43; nnn) $\mathbf{3 0 3}$

Approach span structure type (I - 44; nnn) $\mathbf{0 0 0}$

Number of spans (I - 45; nnn) $\mathbf{0 0 1}$

Number of approach spans (I - 46; nnnn) $\mathbf{0 0 0 0}$

Comments:

The structural inspection report of $09 / 29 / 93$ indicates the structure is a steel stringer type bridge with a bare concrete deck. At the upstream end of the right abutment wall there is a large void, with a rotten log foundation exposed. There is some settlement in the stone work above this log. The main portion of the right abutment wall is clean. The left abutment wall consists of a lower mortared stone section with newer concrete cap above. It appears that the US end of the concrete has settled. There is a shallow void still beneath it, near the center line of roadway. Along the bottom of the stone work there is a log foundation exposed. There is a large flat rock on top of the stone work at the US end of the wall, (Continued, page 33) 


\section{Bridge Hydrologic Data}

Is there hydrologic data available? $\underline{\mathbf{N}}$ if No, type ctrl-n $h \quad$ VTAOT Drainage area $\left(m i^{2}\right)$ : -

Terrain character:

Stream character \& type: -

Streambed material:

Discharge Data (cfs):

$$
\begin{aligned}
& Q_{2.33}- \\
& Q_{50}-
\end{aligned}
$$

Record flood date $(M M / D D / Y Y)$ :

Estimated Discharge (cfs): Ice conditions (Heavy, Moderate, Light) : -

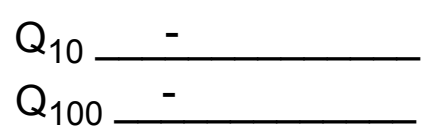

$$
\begin{aligned}
& Q_{25}- \\
& Q_{500}-
\end{aligned}
$$

Water surface elevation $(f t):-$

The stage increases to maximum highwater elevation (Rapidly, Not rapidly):

The stream response is (Flashy, Not flashy):

Describe any significant site conditions upstream or downstream that may influence the stream's stage: -

Watershed storage area (in percent): _ _ \%

The watershed storage area is: - (1-mainly at the headwaters; 2- uniformly distributed; 3-immediatly upstream oi the site)

Water Surface Elevation Estimates for Existing Structure:

\begin{tabular}{|l|l|l|l|l|l|}
\hline Peak discharge frequency & $Q_{2.33}$ & $Q_{10}$ & $Q_{25}$ & $Q_{50}$ & $Q_{100}$ \\
Water surface elevation (ft)) & - & - & - & - & - \\
Velocity (ft/sec) & - & - & - & - & - \\
\hline
\end{tabular}

Long term stream bed changes: -

Is the roadway overtopped below the $\mathrm{Q}_{100}$ ? (Yes, No, Unknown): $\mathbf{U} \quad$ Frequency: Relief Elevation (ft): Discharge over roadway at $Q_{100}\left(f^{3} / \mathrm{sec}\right)$ :

Are there other structures nearby? (Yes, No, Unknown): $\underline{\mathbf{U}}$ Upstream distance (miles): Town: If No or Unknown, type ctrl-n os Highway No. : Structure No. : Year Built:

Clear span (ft): Clear Height $(f t)$ : Full Waterway $\left(f^{2}\right)$ : 
Downstream distance (miles): Town: Year Built:

Highway No. : Structure No. : Structure Type:

Clear span $(f t):$ Clear Height $(f t)$ : Full Waterway $\left(f^{2}\right)$ :

Comments:

which apparently has settled at its right end, directly below the concrete section of the wall. The downstream end of the left abutment is in good condition. There is some wash at this location. All four wingwalls are laid up stone. They have some bulges and lean out somewhat at the right abutment. The waterway has a slight turn just upstream. The streambed consists of stone and gravel, with some random boulders. The right abutment side of the channel is well protected with stone fill.

\section{USGS Watershed Data}

Watershed Hydrographic Data

Drainage area $(D A) \underline{80.61} \mathrm{mi}^{2}$

Watershed storage (ST)

Bridge site elevation 532

Main channel length 17.53 $10 \%$ channel length elevation $\mathbf{5 6 0}$

Main channel slope (S) 69.96 $\mathrm{ft} / \mathrm{mi}$ $\%$ $\mathrm{mi}$

Lake/pond/swamp area

0.217 $\mathrm{mi}^{2}$ Headwater elevation 2882 $\mathrm{ft}$ $\mathrm{ft} \quad 85 \%$ channel length elevation 1480 $\mathrm{ft}$

Watershed Precipitation Data

Average site precipitation in Average headwater precipitation in

Maximum 2yr-24hr precipitation event $(124,2)$ in

Average seasonal snowfall (Sn) $\mathrm{ft}$ 


\section{Bridge Plan Data}

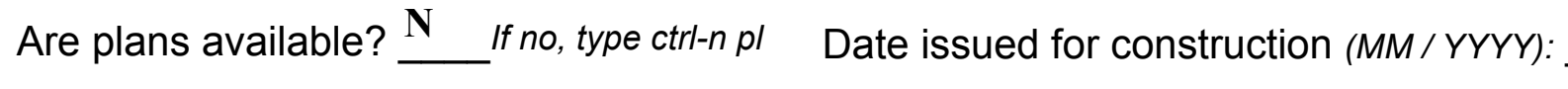

Project Number

Minimum channel bed elevation:

Low superstructure elevation: USLAB DSLAB USRAB DSRAB Benchmark location description:

NO BENCHMARK INFORMATION

Reference Point (MSL, Arbitrary, Other): Datum (NAD27, NAD83, Other):

Foundation Type: 4

If 1: Footing Thickness

If 2: Pile Type: (1-Wood; 2-Steel or metal; 3-Concrete)

If 3 : Footing bottom elevation:

Is boring information available? $\mathbf{N}$ If no, type ctrl-n bi Number of borings taken:

Foundation Material Type: $\mathbf{3}$ (1-regolith, 2-bedrock, 3-unknown)

Briefly describe material at foundation bottom elevation or around piles:

NO FOUNDATION MATERIAL INFORMATION

Comments:

NO PLANS 


\section{Cross-sectional Data}

Is cross-sectional data available? Yes If no, type ctrl-n xs

Source (FEMA, VTAOT, Other)? FEMA

Comments: The elevations and stations are measured in feet.

\begin{tabular}{|l|l|l|l|l|l|l|l|l|l|l|l|}
\hline Station & $\mathbf{1 3 8 0}$ & $\mathbf{1 3 8 0 . 5}$ & $\mathbf{1 3 8 1}$ & $\mathbf{1 3 8 1 . 1}$ & $\mathbf{1 3 8 3}$ & $\mathbf{1 3 8 3 . 1}$ & $\mathbf{1 4 1 3}$ & $\mathbf{1 4 4 8 . 9}$ & $\mathbf{1 4 4 9}$ & $\mathbf{1 4 5 0 . 5}$ & $\mathbf{1 4 5 1 . 1}$ \\
\hline Feature & LB & - & - & - & - & - & - & - & - & - & \\
\hline $\begin{array}{l}\text { Low chord } \\
\text { elevation }\end{array}$ & $\mathbf{5 3 0 . 1}$ & $\mathbf{5 3 0 . 1}$ & $\mathbf{5 3 0 . 1}$ & $\mathbf{5 3 0 . 1}$ & $\mathbf{5 3 0 . 2}$ & $\mathbf{5 3 0 . 2}$ & $\mathbf{5 3 0 . 8}$ & $\mathbf{5 3 1 . 5}$ & $\mathbf{5 3 1 . 5}$ & $\mathbf{5 3 1 . 5}$ & $\mathbf{5 3 1 . 5}$ \\
\hline $\begin{array}{l}\text { Bed } \\
\text { elevation }\end{array}$ & $\mathbf{5 3 0 . 1}$ & $\mathbf{5 2 7 . 1}$ & $\mathbf{5 2 7 . 1}$ & $\mathbf{5 2 5 . 1}$ & $\mathbf{5 2 5 . 1}$ & $\mathbf{5 1 6 . 6}$ & $\mathbf{5 1 4 . 6}$ & $\mathbf{5 1 6 . 7}$ & $\mathbf{5 1 9 . 7}$ & $\mathbf{5 1 9 . 7}$ & $\mathbf{5 2 5 . 7}$ \\
\hline $\begin{array}{l}\text { Low chord } \\
\text { to bed }\end{array}$ & $\mathbf{0}$ & $\mathbf{3 . 0}$ & $\mathbf{3 . 0}$ & $\mathbf{5 . 0}$ & $\mathbf{5 . 1}$ & $\mathbf{1 3 . 6}$ & $\mathbf{1 6 . 2}$ & $\mathbf{1 4 . 8}$ & $\mathbf{1 1 . 8}$ & $\mathbf{1 1 . 8}$ & 5.8 \\
\hline Station & $\mathbf{1 4 5 3 . 9}$ & $\mathbf{1 4 5 4}$ & $\mathbf{1 4 5 5}$ & $\mathbf{1 4 5 6}$ & - & - & - & - & - & - & - \\
\hline Feature & - & - & - & $\mathbf{R B}$ & - & - & - & - & - & - & - \\
\hline $\begin{array}{l}\text { Low chord } \\
\text { elevation }\end{array}$ & $\mathbf{5 3 1 . 6}$ & $\mathbf{5 3 1 . 6}$ & $\mathbf{5 3 1 . 6}$ & $\mathbf{5 3 1 . 7}$ & - & - & - & - & - & - & - \\
\hline $\begin{array}{l}\text { Bed } \\
\text { elevation }\end{array}$ & $\mathbf{5 2 5 . 7}$ & $\mathbf{5 2 6 . 7}$ & $\mathbf{5 2 6 . 7}$ & $\mathbf{5 3 1 . 7}$ & - & - & - & - & - & - & - \\
\hline $\begin{array}{l}\text { Low chord } \\
\text { to bed }\end{array}$ & $\mathbf{5 . 9}$ & $\mathbf{4 . 9}$ & $\mathbf{4 . 9}$ & $\mathbf{0}$ & - & - & - & - & - & - & - \\
\hline
\end{tabular}

Source (FEMA, VTAOT, Other)?

Comments:

\begin{tabular}{|l|l|l|l|l|l|l|l|l|l|l|l|}
\hline Station & - & - & - & - & - & - & - & - & - & - & - \\
\hline Feature & - & - & - & - & - & - & - & - & - & - & - \\
\hline $\begin{array}{l}\text { Low chord } \\
\text { elevation }\end{array}$ & - & - & - & - & - & - & - & - & - & - & - \\
\hline $\begin{array}{l}\text { Bed } \\
\text { elevation }\end{array}$ & - & - & - & - & - & - & - & - & - & - & - \\
\hline $\begin{array}{l}\text { Low chord } \\
\text { to bed }\end{array}$ & - & - & - & - & - & - & - & - & - & - & - \\
\hline Station & - & - & - & - & - & - & - & - & - & - & - \\
\hline Feature & - & - & - & - & - & - & - & - & - & - & - \\
\hline $\begin{array}{l}\text { Low chord } \\
\text { elevation }\end{array}$ & - & - & - & - & - & - & - & - & - & - & - \\
\hline $\begin{array}{l}\text { Bed } \\
\text { elevation }\end{array}$ & - & - & - & - & - & - & - & - & - & - & - \\
\hline $\begin{array}{l}\text { Low chord } \\
\text { to bed }\end{array}$ & - & - & - & - & - & - & - & - & - & - & - \\
\hline
\end{tabular}




\section{APPENDIX E: \\ LEVEL I DATA FORM}


U. S. Geological Survey

Bridge Field Data Collection and Processing Form

Qa/Qc Check by: RB

Date: $\mathbf{0 1 / 2 7 / 9 7}$

\section{Structure Number}

\section{A. General Location Descriptive}

1. Data collected by (First Initial, Full last name) L. MEDALIE

Date $(M M / D D / Y Y) \underline{08} / \underline{19} / 1996$

2. Highway District Number $\mathbf{0 2}$

County Windsor (27)

Waterway (I - 6) Williams River

Route Number $\mathbf{\text { TH006 }}$

3. Descriptive comments:

This site is located 0.3 miles from the junction with VT 103.
Mile marker $\mathbf{0 0 0 0}$

Town Chester (13675)

Road Name -

Hydrologic Unit Code: $\mathbf{0 1 0 8 0 1 0 7}$

\section{B. Bridge Deck Observations}
4. Surface cover... LBUS 3
RBUS 6
LBDS 3
RBDS 4
Overall $\mathbf{3}$

(2b us,ds,lb,rb: 1- Urban; 2- Suburban; 3- Row crops; 4- Pasture; 5- Shrub- and brushland; 6- Forest; 7- Wetland)
5. Ambient water surface... US 2
UB 1
DS 1
(1- pool; 2- riffle)

6. Bridge structure type 1 (1- single span; 2- multiple span; 3- single arch; 4- multiple arch; 5-cylindrical culvert; 6- box culvert; or 7- other)
7. Bridge length $\mathbf{8 2}$ (feet)
Span length $\mathbf{7 8}$
(feet)
Bridge width 12.8 (feet)

\section{Road approach to bridge:}
8. LB 1
RB 2
( 0 even, 1- lower, 2- higher)
9. LB_2
RB $\underline{2}$
(1- Paved, 2- Not paved)

10. Embankment slope (run / rise in feet / foot)

US left

US right

\begin{tabular}{|c|c|c|c|}
\hline \multicolumn{2}{|c|}{ Protection } & \multirow{2}{*}{ 13.Erosion } & 14.Severity \\
\hline 11.Type & 12.Cond. & $\underline{\mathbf{2}}$ & $\underline{\mathbf{2}}$ \\
\hline $\mathbf{3}$ & $\underline{\mathbf{2}}$ & $\underline{\mathbf{2}}$ & $\underline{\mathbf{2}}$ \\
\hline $\mathbf{5}$ & $\mathbf{1}$ & $\underline{\mathbf{2}}$ & $\mathbf{1}$ \\
\hline $\mathbf{0}$ & - & $\mathbf{0}$ & $\mathbf{-}$ \\
\hline $\mathbf{0}$ & - & $\mathbf{0}$ & $\underline{\mathbf{0}}$ \\
\hline
\end{tabular}

Bank protection types: 0- none; 1- < 12 inches;

2- < 36 inches; 3- < 48 inches;

4- < 60 inches; 5- wall / artificial levee

Bank protection conditions: 1- good; 2- slumped;

3- eroded; 4- failed

Erosion: 0 - none; 1- channel erosion; 2-

road wash; 3- both; 4- other

Erosion Severity: 0 - none; 1- slight; 2- moderate;

\section{Channel approach to bridge (BF):}

15. Angle of approach: $\mathbf{0}$

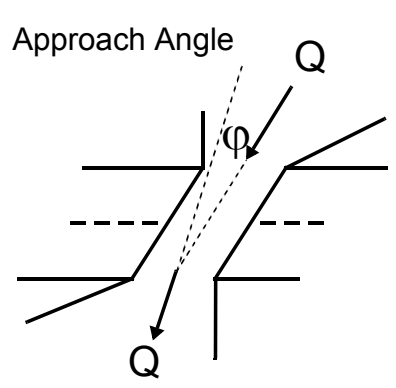

17. Channel impact zone 1 :

Where? RB (LB, RB)

Range? 330 feet US

Channel impact zone 2:

Where? RB (LB, RB)

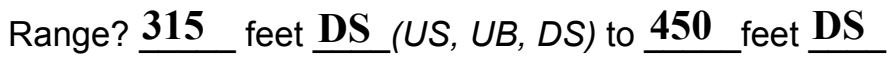

Impact Severity: 0- none to very slight; 1- Slight; 2- Moderate; 3- Severe
16. Bridge skew: $\mathbf{0}$ Bridge Skew Angle

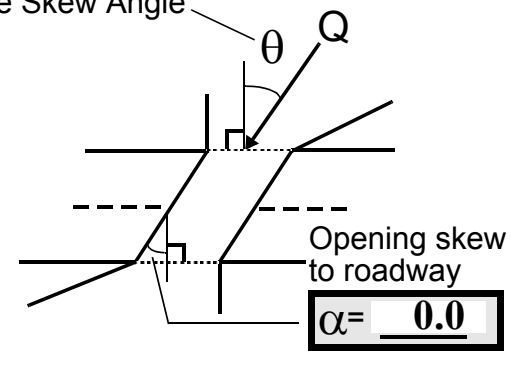

\section{Exist? $\mathbf{Y}(Y$ or $N)$}

Severity 2

(US, UB, DS) to 100 feet $\underline{\mathbf{U S}}$

Exist? $\mathbf{Y}(Y$ or $N)$

Severity 1 
18. Bridge Type: $\mathbf{1 b}$

1a- Vertical abutments with wingwalls

$1 \mathrm{~b}$ - Vertical abutments without wingwalls

2- Vertical abutments and wingwalls, sloping embankment Wingwalls parallel to abut. face

3- Spill through abutments

4- Sloping embankment, vertical wingwalls and abutments

Wingwall angle less than $90^{\circ}$.

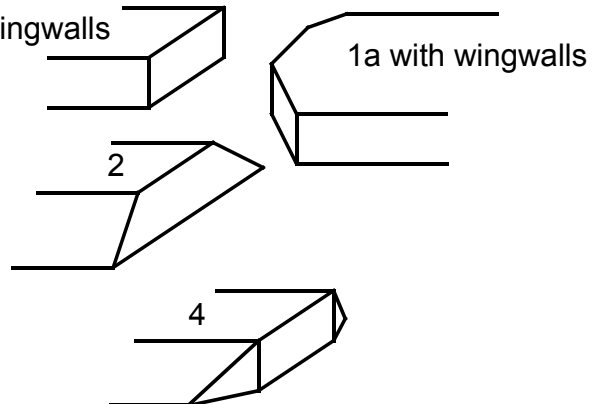

19. Bridge Deck Comments (surface cover variations, measured bridge and span lengths, bridge type variations, approach overflow width, etc.)

7. The bridge dimension values are from the VTAOT files. The measured bridge length is $81.5 \mathrm{ft}$, bridge span is $\mathbf{7 7 . 5} \mathrm{ft}$ and bridge width is $\mathbf{1 5 . 3} \mathrm{ft}$ from the outside base plate of the metal rail on both sides.

18. The wingwalls mentioned in the historical form are laid up stone walls wrapping around the sides of both abutments except the at the US end of the left abutment.

11. The laid up stone wingwall is considered protection for the right bank US. The DS left wingwall also acts as protection.

\section{Upstream Channel Assessment}

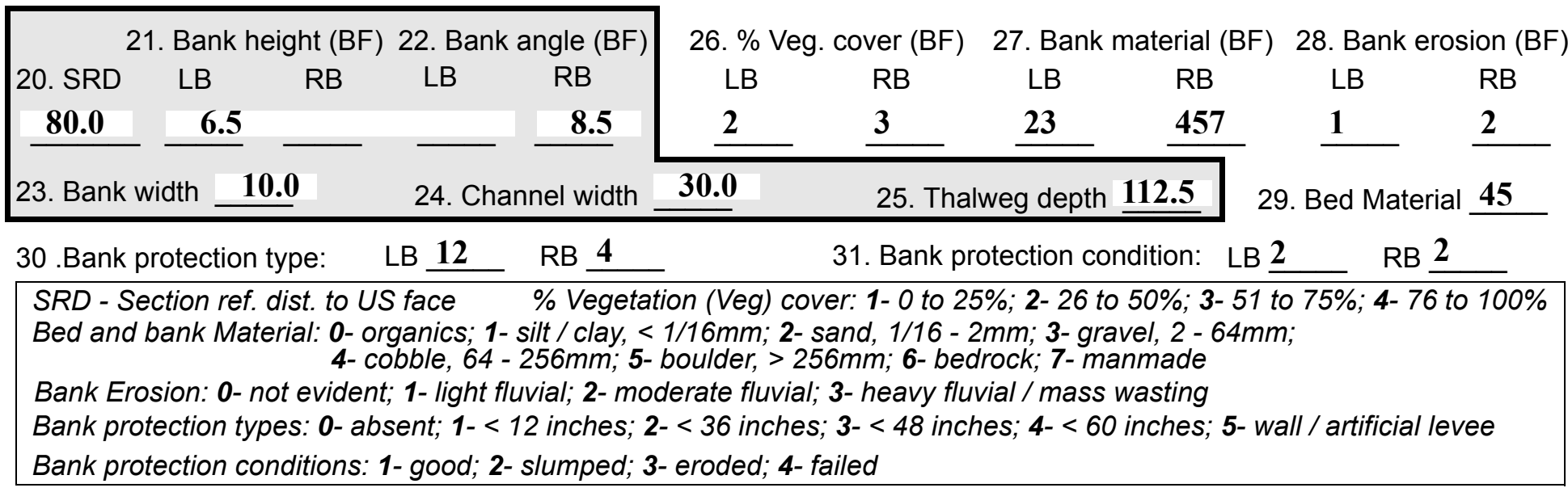

32. Comments (bank material variation, minor inflows, protection extent, etc.):

30. The right and left bank protection extends from the bridge to $28 \mathrm{ft}$ US.

27. For a $10 \mathrm{ft}$ stretch, there are a few long flat stones built into a wall halfway up the right bank at the approach. 
36. Point bar extent: $\underline{\mathbf{2 3 0}}$ feet $\underline{\text { US }}$ (US, UB) to $\underline{\mathbf{3 9}}$ feet $\underline{\mathrm{DS}}$ (US, UB, DS) positioned $\underline{\mathbf{5}} \%$ LB to $\underline{\mathbf{3 5}} \% \mathrm{RB}$

37. Material: $\mathbf{3 4}$

38. Point or side bar comments (Circle Point)or Side; Note additional bars, material variation, status, etc.):

Point bar consisting of gravel and boulder.

39. Is a cut-bank present? $\mathbf{Y}$ (Yor if $N$ type ctrl-n $c b)$

41. Mid-bank distance: 275

43. Bank damage: 2

42. Cut bank extent: 46

40. Where? $\mathbf{R B} \quad(L B$ or $R B)$ feet $\underline{\mathbf{U S}}$ (US, UB) to $\underline{\mathbf{2 9 0}}$ feet $\underline{\mathrm{US}}$ (US, UB, DS)

(1- eroded and/or creep; 2- slip failure; 3- block failure)

44. Cut bank comments (eg. additional cut banks, protection condition, etc.):

Some type-3 protection on the right bank is slumped from $285 \mathrm{ft}$ US to $245 \mathrm{ft}$ US.

45. Is channel scour present? $\mathbf{N}$ ( $Y$ or if $N$ type ctrl-n cs)

47. Scour dimensions: Length -

Width -

Depth :-

46. Mid-scour distance: -

48. Scour comments (eg. additional scour areas, local scouring process, etc.):

NO CHANNEL SCOUR

49. Are there major confluences? $\mathbf{N}$

51. Confluence 1: Distance -

Confluence 2: Distance -

54. Confluence comments (eg. confluer

NO MAJOR CONFLUENCES
( $Y$ or if $N$ type ctrl-n $m c$ )

52. Enters on -

Enters on (LB or $R B)$ (LB or $R B)$
50. How many? -

53. Type(1- perennial; 2- ephemeral)

Type (1- perennial; 2- ephemeral)

\section{Under Bridge Channel Assessment}

55. Channel restraint (BF)? LB 2

\begin{tabular}{|ccccc}
\hline \multicolumn{2}{|c}{ 56. Height (BF) } & \multicolumn{3}{c}{57 Angle (BF) } \\
LB & RB & LB & RB \\
$\mathbf{6 7 . 0}$ & & & $\mathbf{1 . 0}$ & \\
\hline
\end{tabular}

58. Bank width (BF) (1- natural bank; 2- abutment; 3- artificial levee)

Bed and bank Material: 0- organics; 1- silt / clay, < 1/16mm; 2- sand, 1/16 - 2mm; 3- gravel, 2 - 64mm; 4- cobble, 64 - 256mm; 5- boulder, > 256mm; 6- bedrock; 7- manmade

61. Material $(\mathrm{BF}) \quad$ 62. Erosion $(\mathrm{BF})$

LB RB LB RB

$\underline{2} \quad \underline{7} \quad \underline{7}$

59. Channel width -

60. Thalweg depth $\quad \mathbf{9 0 . 0}$

63. Bed Material -

Bank Erosion: 0- not evident; 1- light fluvial; 2- moderate fluvial; 3- heavy fluvial / mass wasting

64. Comments (bank material variation, minor inflows, protection extent, etc.):

435

63. The bed material is gravel towards the left of the channel and boulders toward the right. 
65. Debris and Ice Is there debris accumulation?

67. Debris Potential (1- Low; 2- Moderate; 3- High)

69. Is there evidence of ice build-up? 1

70. Debris and Ice Comments:
$(Y$ or $N)$ 66. Where? $\mathbf{N}$

68. Capture Efficiency 1

(1- Upstream; 2- At bridge; 3-Both)

Ice Blockage Potential $\underline{\mathbf{N}}$
(1-Low; 2- Moderate; 3- High)

(1-Low; 2- Moderate; 3- High) 1

\begin{tabular}{|l|c|c|c|c|c|c|c|c|}
\hline Abutments & $\begin{array}{c}\text { 71. Attack } \\
\angle \text { (BF) }\end{array}$ & $\begin{array}{c}\text { 72. Slope } \angle \\
\text { (Qmax) }\end{array}$ & $\begin{array}{c}\text { 73. Toe } \\
\text { loc. (BF) }\end{array}$ & $\begin{array}{c}\text { 74. Scour } \\
\text { Condition }\end{array}$ & $\begin{array}{c}\text { 75. Scour } \\
\text { depth }\end{array}$ & $\begin{array}{c}\text { 76. Exposure } \\
\text { depth }\end{array}$ & 77. Material & 78. Length \\
\hline LABUT & & $\mathbf{0}$ & $\mathbf{9 0}$ & $\mathbf{2}$ & $\mathbf{0}$ & - & - & $\mathbf{9 0 . 0}$ \\
\hline RABUT & $\mathbf{1}$ & $\mathbf{0}$ & $\mathbf{8 5}$ & & & $\mathbf{2}$ & $\mathbf{3}$ & $\mathbf{7 5 . 5}$ \\
\hline
\end{tabular}

Pushed: $L B$ or RB

Toe Location (Loc.): 0- even, 1- set back, 2- protrudes

Scour cond.: 0- not evident; 1- evident (comment); 2- footing exposed; 3-undermined footing; 4- piling exposed; 5- settled; 6- failed

Materials: 1- Concrete; 2- Stone masonry or drywall; 3- steel or metal; 4- wood

79. Abutment comments (eg. undermined penetration, unusual scour processes, debris, etc.):

2

4

1

77. The left abutment has a stone and log base $8.5 \mathrm{ft}$ high with a concrete cap set back from it. The right abutment has a concrete base with a concrete cap set back from it at a different angle.

71. The bottom half of the right abutment is parallel to flow. The top half of the abutment has a 45 degree attack angle. The US end of the right abutment protrudes into the channel and water is hitting it straight on.

74. The lower footing of the right abutment is undermined $1.5 \mathrm{ft}$ at the US most corner only.

75. Average thalweg depth is $1 \mathrm{ft}$ and the water depth at the US end is $3 \mathrm{ft}$.

76. The lower footing is exposed $4 \mathrm{ft}$ at the US end and only $1 \mathrm{ft}$ at the DS end.

80. Wingwalls:

$\begin{array}{lcccc}\text { Exist? Material? } & \text { Scour } & \text { Scour Exposure } & & \\ \text { Angle? Length? } & \text { Condition? depth? depth? }\end{array}$

USLWW:

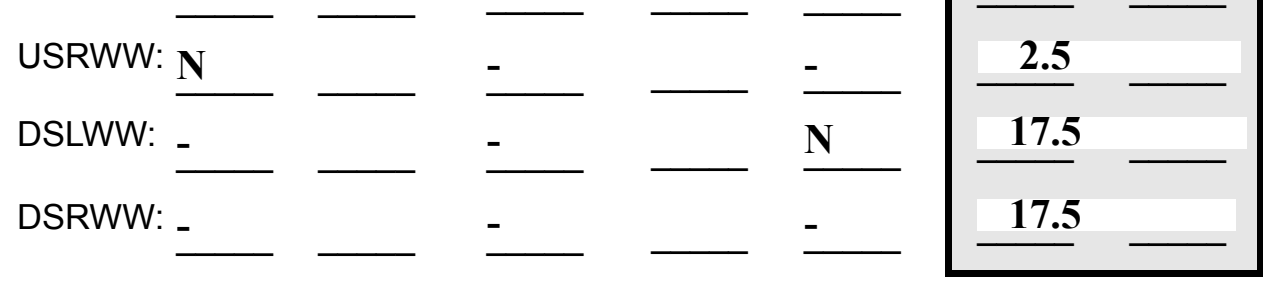

Wingwall materials: 1- Concrete; 2- Stone masonry or drywall; 3- steel or metal; 4- wood

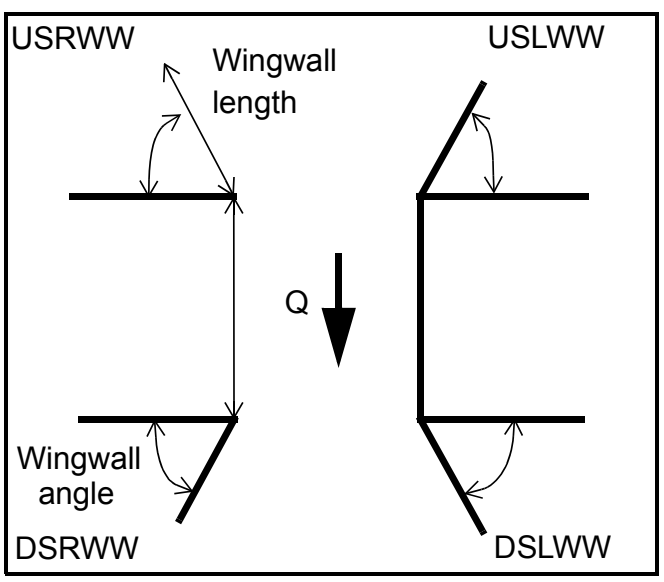

82. Bank / Bridge Protection:

\begin{tabular}{|l|l|l|l|l|l|l|l|c|}
\hline Location & USLWW & USRWW & LABUT & RABUT & LB & RB & DSLWW & DSRWW \\
\hline Type & - & - & N & - & - & - & - & $\mathbf{2}$ \\
\hline Condition & N & - & - & - & - & - & - & $\mathbf{4}$ \\
\hline Extent & - & - & - & - & - & $\mathbf{0}$ & $\mathbf{2}$ & - \\
\hline
\end{tabular}

Bank / Bridge protection types: 0- absent; 1- < 12 inches; 2- < 36 inches; 3- < 48 inches; 4- < 60 inches; 
83. Wingwall and protection comments (eg. undermined penetration, unusual scour processes, etc.):

-
-
-
-
-
-
-
-
-
-

\section{Piers:}

84. Are there piers? 82. (Y or if $N$ type ctrl-n pr)

\begin{tabular}{|l|l|l|l|l|l|l|l|}
\hline \multirow{2}{*}{$\begin{array}{l}85 . \\
\text { Pier no. }\end{array}$} & \multicolumn{3}{|c|}{ width (w) feet } & \multicolumn{3}{c|}{ elevation (e) feet } \\
\cline { 2 - 9 } & w1 & w2 & w3 & e@w1 & e@w2 & e@w3 \\
\hline Pier 1 & - & - & - & - & - & - \\
\hline Pier 2 & - & - & - & - & - & - \\
\hline Pier 3 & - & - & - & - & - & - \\
\hline Pier 4 & - & - & - & - & - & - \\
\hline
\end{tabular}

\begin{tabular}{|l|l|l|l|l|}
\hline Level 1 Pier Descr. & \multicolumn{1}{|c|}{1} & \multicolumn{1}{|c|}{2} & \multicolumn{1}{|c|}{3} & \multicolumn{1}{|c|}{ 86. Location (BF) } \\
\hline 87. Type & The & ends, & in & allel to \\
\hline 88. Material & right & not & front & the \\
\hline 89. Shape & abut & in & of & road. \\
\hline 90. Inclined? & ment & the & the & In \\
\hline 91. Attack $\angle$ (BF) & pro- & cen- & laid- & front \\
\hline 92. Pushed & tion & Ther & stone & the \\
\hline 93. Length (feet) & - & - & up & of \\
\hline 94. \# of piles & is at & e is & wing & DS \\
\hline 95. Cross-members & the & also & walls & left \\
\hline 96. Scour Condition & US & pro- & that & and \\
\hline 97. Scour depth & and & tec- & are & right \\
\hline 98. Exposure depth & DS & tion & par- & wing \\
\hline
\end{tabular}

LFP, LTB, LB, MCL, MCM, MCR, RB, RTB, RFP

1- Solid pier, 2- column, 3- bent

1-Wood; 2- concrete; 3- metal; 4- stone

1- Round; 2- Square; 3- Pointed

Y-yes; $N-$ no

$L B$ or $R B$

0- none; 1- laterals; 2- diagonals; 3- both

0- not evident; 1- evident (comment);

2- footing exposed; 3- piling exposed;

4- undermined footing; 5- settled; 6-failed 
99. Pier comments (eg. undermined penetration, protection and protection extent, unusual scour processes, etc.):

walls there is type-2 protection that is slumped along the entire base length of the wall. In front of the US right wingwall is type-3 protection that is also slumped along the base. The US right wingwall bottom stone is also undermined up to $3 \mathrm{ft}$. It is resting on stones on either end with the void in the middle.

$\mathbf{N}$

100.

\section{E. Downstream Channel Assessment}

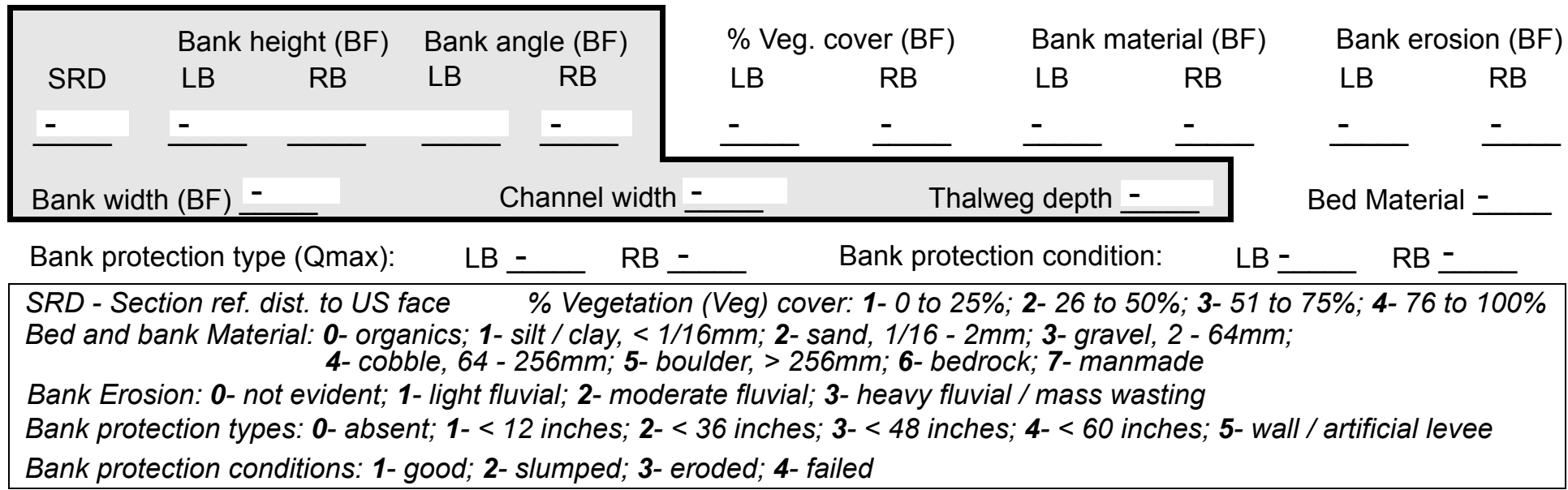

Comments (eg. bank material variation, minor inflows, protection extent, etc.):

$-$

-

-

-

-

-

-

-

$-$

-

\section{Is a drop structure present? __ ( $Y$ or $N$, if $N$ type ctrl-n $d s) \quad$ 102. Distance: ___ feet}
103. Drop: - feet
104. Structure material: -
(1- steel sheet pile; 2- wood pile; 3- concrete; 4- other)

105. Drop structure comments (eg. downstream scour depth): 
106. Point/Side bar present? (Y or $N$. if $N$ type ctrl-n pb)Mid-bar distance:

Mid-bar width: -

Point bar extent: feet -

(US, UB, DS) to feet (US, UB, DS) positioned $\%$ LB to $\% \mathrm{RB}$ Material:

Point or side bar comments (Circle Point or Side; note additional bars, material variation, status, etc.):

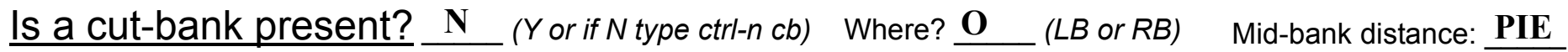
Cut bank extent: RS feet__ (US, UB, DS) to feet (US, UB, DS)

Bank damage: (1- eroded and/or creep; 2- slip failure; 3- block failure)

Cut bank comments (eg. additional cut banks, protection condition, etc.):

Is channel scour present? Scour dimensions: Length 2 Width 23 ( $Y$ or if $N$ type ctrl-n cs) Depth: 23 Mid-scour distance: $\underline{\mathbf{3}}$ Scour comments (eg. additional scour areas, local scouring process, etc.): 345

2

2

1

Are there major confluences? 1 ( 1 or if $N$ type ctrl-n $m c)$ Confluence 1: Distance left Enters on ban ( $L B$ or $R B)$ Enters on tatio ( $L B$ or $R B$ )

Positioned $\underline{1}$ $\%$ LB to 2 $\%$ RB

How many? The

Type $\underline{\mathbf{k}}$

Confluence 2: Distance vegeType $\underline{\mathbf{n}}$

Confluence comments (eg. confluence name): (1- perennial; 2- ephemeral) (1- perennial; 2- ephemeral)

cover is small trees and large shrubs. The right bank protection consists of boulders in the channel from the DS face to $53 \mathrm{ft}$ DS. The left bank protection extends from the bridge face to $35 \mathrm{ft}$ DS. It is grown over with

\section{F. Geomorphic Channel Assessment}

107. Stage of reach evolution

1- Constructed

2- Stable

3- Aggraded

4- Degraded

5- Laterally unstable

6- Vertically and laterally unstable 
108. Evolution comments (Channel evolution not considering bridge effects; See HEC-20, Figure 1 for geomorphic descriptors):

etation. A railroad bridge is located $500 \mathrm{ft}$ DS, just DS of the confluence. 


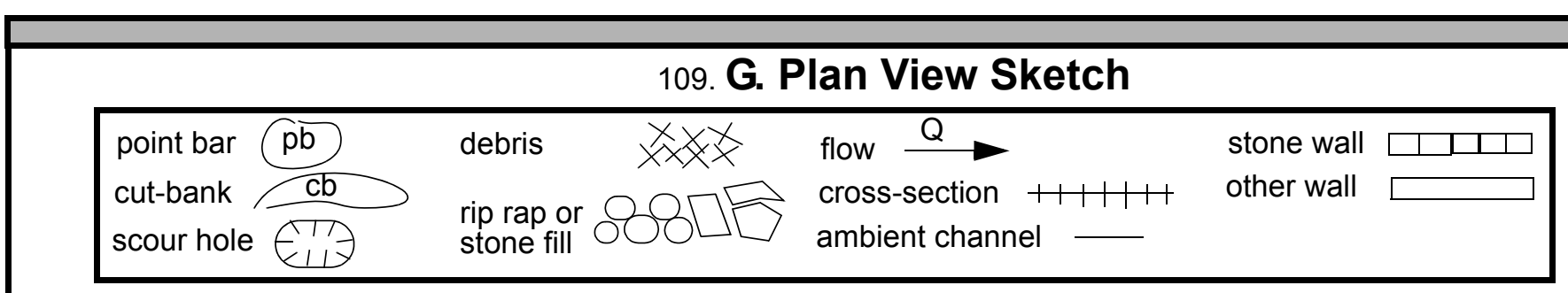


APPENDIX F:

SCOUR COMPUTATIONS 


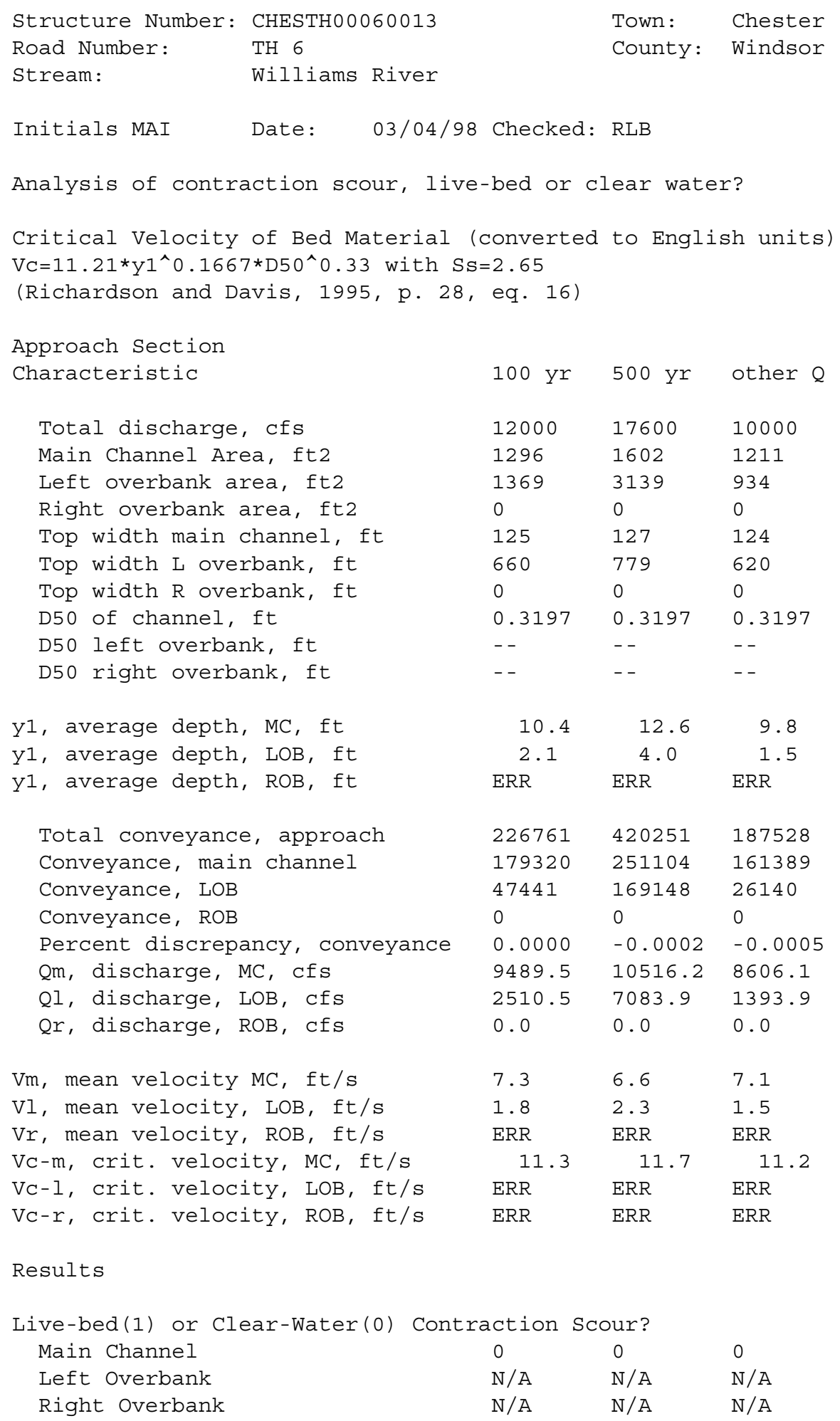




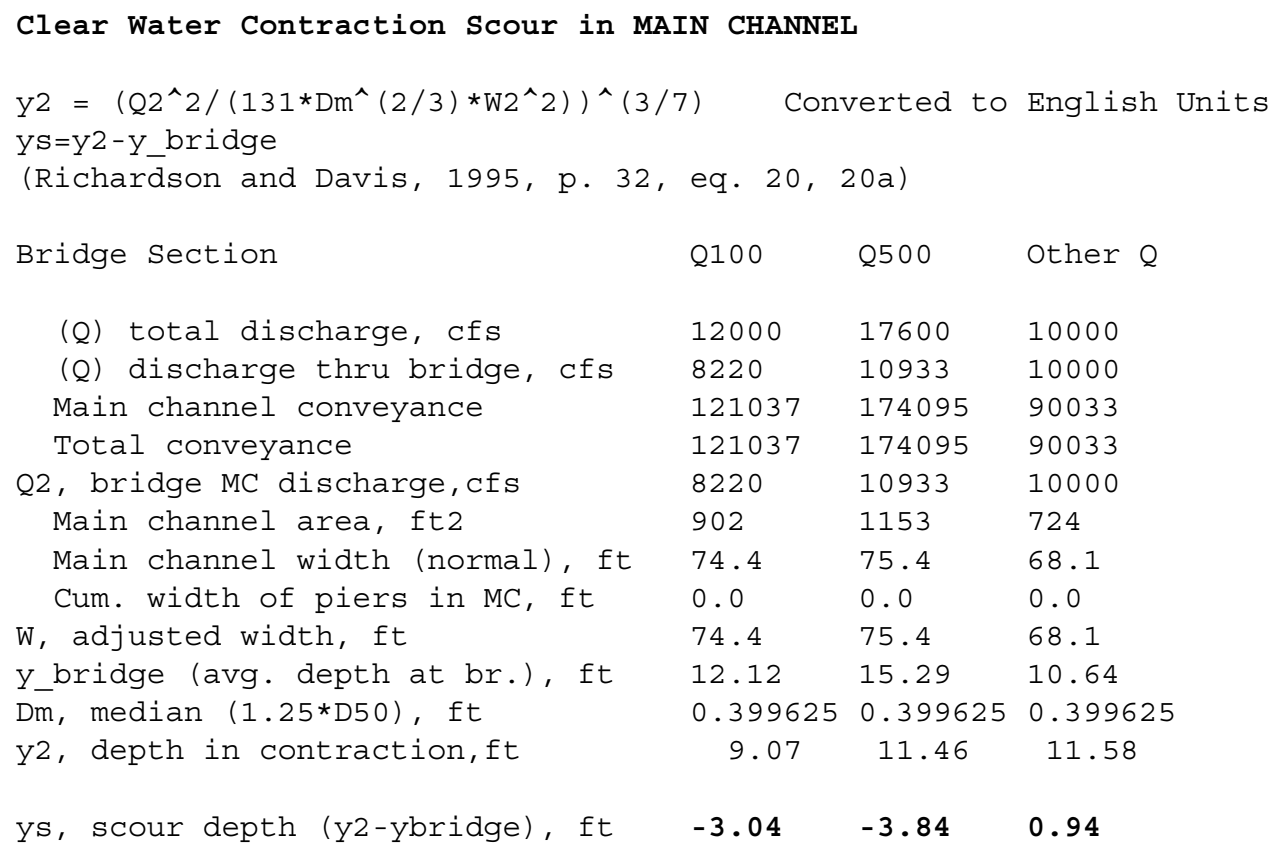

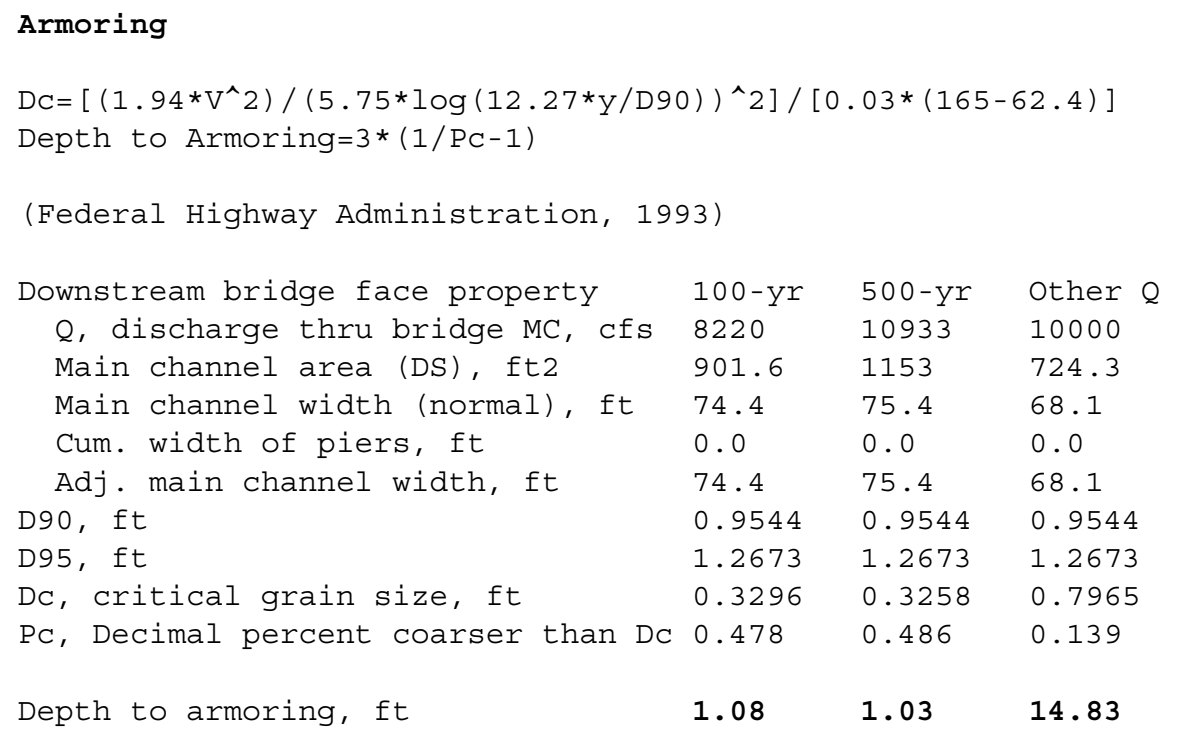




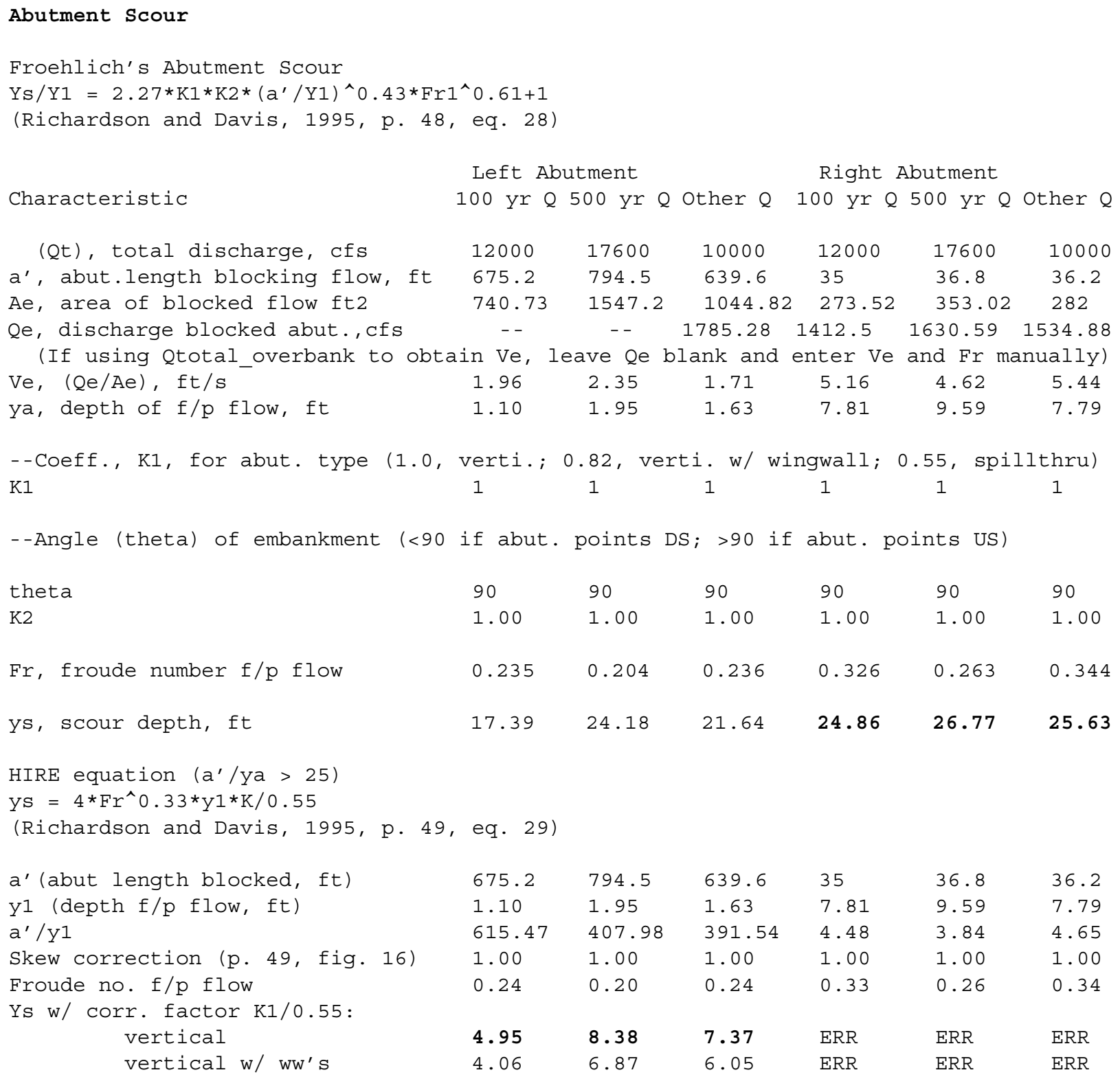

$\begin{array}{lllllll}\text { vertical } & 4.95 & \mathbf{8 . 3 8} & \mathbf{7 . 3 7} & \text { ERR } & \text { ERR } & \text { ERR } \\ \text { vertical w/ } \text { WW' }^{\prime} \mathrm{S} & 4.06 & 6.87 & 6.05 & \text { ERR } & \text { ERR } & \text { ERR }\end{array}$



spill-through
2.72
4.61
4.06
ERR
ERR
ERR

Abutment riprap Sizing

Isbash Relationship

$\mathrm{D} 50=\mathrm{Y} * \mathrm{~K} * \mathrm{Fr} \wedge 2 /(\mathrm{SS}-1)$ and $\mathrm{D} 50=\mathrm{Y} * \mathrm{~K} *\left(\mathrm{Fr}^{\wedge} 2\right)^{\wedge} 0.14 /(\mathrm{SS}-1)$

(Richardson and Davis, 1995, p112, eq. 81,82)

\begin{tabular}{|c|c|c|c|c|c|c|}
\hline Characteristic & Q100 & Q500 & Other $\mathrm{Q}$ & Q100 & Q500 & Other Q \\
\hline Fr, Froude Number & 0.57 & 0.43 & 0.81 & 0.57 & 0.43 & 0.81 \\
\hline$y$, depth of flow in bridge, ft & 12.12 & 15.29 & 10.64 & 12.12 & 15.29 & 10.64 \\
\hline Median stone Diameter for riprap & $t:$ left & butment & & right & abutment, & ft \\
\hline Fr<=0.8 (vertical abut.) & 2.43 & 1.75 & $\mathrm{ERR}$ & 2.43 & 1.75 & $\mathrm{ERR}$ \\
\hline Fr>0.8 (vertical abut.) & ERR & ERR & 4.19 & ERR & ERR & 4.19 \\
\hline
\end{tabular}

